6-1-2008

\title{
Adaptations to Host Infection and Larval Parasitism in Unionoida
}

\author{
M. Christopher Barnhart \\ Missouri State University \\ Wendell R. Haag \\ William N. Roston
}

Follow this and additional works at: https://bearworks.missouristate.edu/articles-cnas

\section{Recommended Citation}

Barnhart, M. Christopher, Wendell R. Haag, and William N. Roston. "Adaptations to Host Infection and Larval Parasitism in Unionoida." Journal of the North American Benthological Society 27, no. 2 (2008): 370-394.

This article or document was made available through BearWorks, the institutional repository of Missouri State University. The work contained in it may be protected by copyright and require permission of the copyright holder for reuse or redistribution.

For more information, please contact BearWorks@library.missouristate.edu. 


\title{
Adaptations to host infection and larval parasitism in Unionoida
}

\author{
M. Christopher Barnhart ${ }^{1}$ \\ Biology Department, Missouri State University, Springfield, Missouri 65897 USA \\ Wendell R. Haag ${ }^{2}$ \\ Center for Bottomland Hardwoods Research, Southern Research Station, US Department of Agriculture \\ Forest Service, 1000 Front St., Oxford, Mississippi 38655 USA \\ William N. Roston ${ }^{3}$ \\ Rural Route 14, Sparta, Missouri 65753 USA
}

\begin{abstract}
Freshwater mussel larval parasitism of fish is unique among bivalves. The relationship is primarily phoretic rather than nutritive; only the smallest glochidia and the haustorial larva grow substantially while on the host. Growth of the smallest larvae suggests a lower functional size limit of $\sim 150$ $\mu \mathrm{m}$ for the juvenile stage. Most Ambleminae, the most diverse North American clade, infect host gills by attracting feeding fish. Many species of Pleurobemini and some Lampsilini release conglutinates of eggs and larvae that resemble host food items. Many Lampsilini and a few Quadrulini use mantle modifications to attract host fish to the female. The mantle of some Quadrulini forms a posterior chamber that holds glochidia for immediate release in response to host fish. In many Lampsilini, mantle flap lures and a protrusible marsupium promote attack by the host fish and direct extraction of glochidia from the marsupium by the host. Host extraction of glochidia from the brooding female might have favored the evolution of long-term brooding in Lampsilini because glochidia need not be released by the female to encounter the host. A remarkable derivative of the host extraction strategy evolved in Epioblasma, which catch fish between the valves and release glochidia directly to the trapped host before releasing it. Host specificity is a critical feature of the evolutionary diversification and conservation biology of Unionoida. As temporary parasites, mussels must primarily evade the innate immune responses of the host, rather than the adaptive (acquired) responses. Evolution of host specificity is associated with selective encounter of host taxa, either because of host attraction strategies or because of dominance of particular host species in the habitat. The intricate relationships between mussels and fish are easily disrupted and, thus, contribute to the imperilment of many mussel species, yet they also fascinate us and compel conservation efforts.
\end{abstract}

Key words: Unionoida, parasitism, freshwater mussel, glochidia, innate immunity, host specificity.

Unionoida is a remarkably successful and diverse order of freshwater bivalves, and it includes $\sim 840$ extant species worldwide (Graf and Cummings 2007). The evolutionary diversification of Unionoida is associated with adaptations for larval parasitism on fish hosts. These adaptations have broadly influenced mussel biology, including morphology, behavior, fecundity, reproductive seasonality, adult habitat specialization, and geographic distribution. Many clades

\footnotetext{
${ }^{1}$ E-mail addresses: chrisbarnhart@missouristate.edu

${ }^{2}$ whaag@fs.fed.us

${ }^{3}$ wroston@live.com
}

exhibit particular host-related adaptations that might be important both to understanding evolutionary patterns and to designing effective management strategies.

Understanding of the phylogeny of Unionoida has advanced steadily in recent years (e.g., Lydeard et al. 1996, Graf 2000, Hoeh et al. 2001, 2002, Roe and Hoeh 2003, Campbell et al. 2005, Graf and Cummings 2006). The basal dichotomy among living species lies between the Hyriidae + lasidia-producing families (Etheriidae, Mycetopodidae, and Iridinidae) and the Unionidae + Margaritiferidae (Fig. 1). Approximately $80 \%$ of worldwide diversity of Unionoida lies in the 


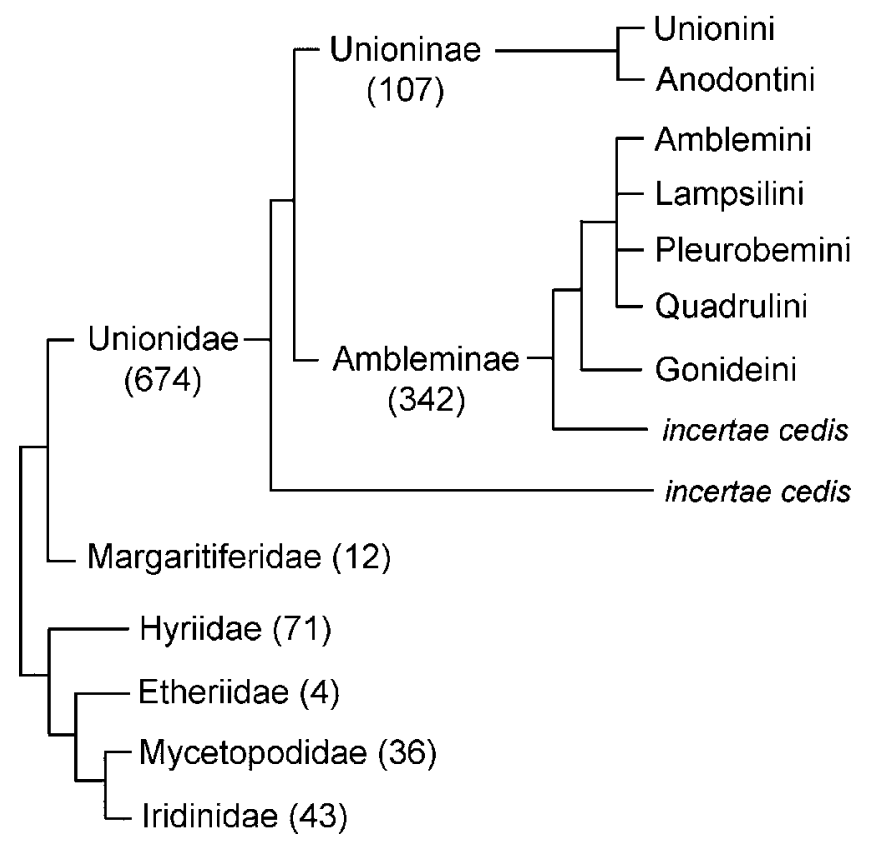

FIG. 1. Phylogenetic classification of Unionoida, adapted from Graf and Cummings (2007). Estimated numbers of species in families and subfamilies are indicated. Classification of North American species referred to in our paper follows Campbell et al. (2005): Margaritiferidae.-Margaritifera, Cumberlandia; Anodontini.-Alasmidonta, Anodonta, Anodontoides, Lasmigona, Pegias, Pyganodon, Strophitus, Simpsonaias, Utterbackia; Gonideini.-Gonidea; Quadrulini.-Cyclonaias, Megalonaias, Quadrula, Quincuncina infucata, Tritogonia; Pleurobemini.-Elliptio, Elliptoideus, Fusconaia, Plethobasus, Pleurobema; Amblemini.-Amblema, Popenaias, Fusconaia ebena; Lampsilini.--Actinonaias, Cyprogenia, Cyrtonaias, Dromus, Epioblasma, Ellipsaria, Glebula, Hamiota, Lampsilis, Leptodea, Ligumia, Medionidus, Obliquaria, Obovaria, Plectomerus, Potamilus, Ptychobranchus, Toxolasma, Truncilla, Venustaconcha, Villosa.

family Unionidae. Unionidae includes 2 subfamilies, the Unioninae and the Ambleminae, as well as several Old World genera of uncertain relationship. Subfamily Unioninae consists of 2 tribes, the Unionini and the Anodontini. Subfamily Ambleminae consists of 5 tribes: Lampsilini, Amblemini, Pleurobemini, Quadrulini, and Gonideini, as well as Old World taxa of uncertain affinity (Graf and Cummings 2006, 2007). Ambleminae includes $\sim 250$ North American species and 37 genera, which represent $85 \%$ of North American species and $75 \%$ of North American genera of Unionoida (Campbell et al. 2005, Graf and Cummings 2006, 2007).

Reproductive characters, particularly larval and female brooding morphologies, have long been used to classify Unionoida. Characters used to evaluate phylogeny must be defined carefully and evaluated for homoplasy. Conversely, accurate phylogeny can help to identify characteristics that have evolved repeatedly, potentially providing clues to their functional significance (Sanderson and Hufford 1996). The purpose of our study is to review and interpret features of reproduction and parasitism from a functional viewpoint, relate them to current phylogenetic hypotheses, and point out fertile areas for new research. The review emphasizes North American taxa. The reader is advised to consult Campbell et al. (2005) for a phylogenetic analysis of North American species. General discussions of mussel parasitism include Lefevre and Curtis (1912), Kat (1984), Jansen et al. (2001), Wächtler et al. (2001), Haag and Warren (2003), and Watters (2006).

\section{Origin of Larval Parasitism}

The evolutionary origin of larval parasitism in Unionoida is not well understood. Unionoid females brood the fertilized eggs during their embryonic development, a feature shared with most other clades of freshwater bivalves (Park and Ó Foighil 2000, Korniushin and Glaubrecht 2003). At least some populations of a few species undergo direct development, but that condition is rare and apparently derived (summarized by Wächtler et al. 2001). Nearly all Unionoida have parasitic larvae that complete development to the juvenile stage while attached to fish. Two primary larval forms are found in Unionoida: the glochidium in Margaritiferidae, Unionidae, and Hyriidae, and the lasidium in Etheriidae, Mycetopodidae, and Iridinidae (Fryer 1961, Wächtler et al. 2001, Graf and Cummings 2006). Glochidia are small bivalves that attach to the fish host by clamping the valves of the shell on fins or gill filaments, with subsequent encapsulation by migration of host epithelial cells (Rogers-Lowery and Dimock 2006). Lasidia lack a calcified shell, and they attach initially via ciliated anterior lobes and posterior hooks. Lasidia of some species are encapsulated and undergo metamorphosis similar to glochidia. In others, the lasidium produces a forked, root-like holdfast (haustorium) that penetrates the host and lengthens to form an external stalk connecting the developing bivalve to the host (Fryer 1961, Wächtler et al. 2001). The morphological disparity between glochidia and lasidia larvae is striking, and the modes of attachment are fundamentally different (Parodiz and Bonetto 1963). In spite of this disparity, parasitism and other synapomorphies argue for monophyly of Unionoida and the derivation of lasidia from glochidia (Graf 2000, Hoeh et al. 2001, Roe and Hoeh 2003, Graf and Cummings 2006).

The relationship between Unionoida and fish 
probably began as phoresy, where juveniles obtain a selective advantage by the resulting upstream dispersal (Watters 2001). Upstream dispersal is the most obvious advantage that mussels gain from their relationship with fish. Some nutrition is derived from the host (Fisher and Dimock 2002), but most Unionoids do not grow on the host (see Growth during encapsulation), and none reproduces there. The origin of larval attachment to fish is a puzzle. Frequent contact with fish and useful phoresis presumably arose first, which provided the opportunity for natural selection and the evolution of specialized larval attachment mechanisms. We suggest that a phoretic relationship might have arisen if larvae using secreted threads for dispersal caught on fish, similar to the larval thread or tentacle of some modern unionoids. Postveliger byssus thread production and dispersal by drift are phylogenetically widespread in marine and freshwater bivalves (Sigurdsson et al. 1976, Prezant and Chalermwat 1984, Lane et al. 1985, Beaumont and Barnes 1992). In flowing water, threads facilitate settlement by catching on projections and coarsegrained substrates (Abelson et al. 1994, Fingerut et al. 2006). Hypothetically, threads could facilitate upstream transport of bivalves by entangling or adhering to fish without parasitism or other mechanisms for attachment. Investigation into whether nonparasitic bivalves such as thread-secreting Corbicula can be transported upstream in this way would be interesting.

If contact with fish and phoresy were routine in the ancestor of Unionoida, adaptations that facilitated mechanical attachment to fish (valve clamping, hooks, haustoria) would have been far more likely to evolve. Initial attachment of other bivalves to surfaces typically involves adhesive secretions from the byssus glands, but this mechanism might not provide firm attachment to mucus-covered epithelia. Mechanical attachment triggers encapsulation by migration of keratocytes, a general defensive response of fish epithelia to attached foreign bodies (Arey 1921, Rogers-Lowery and Dimock 2006). We consider encapsulation and the immunological aspects of parasitism in the section titled Evolution of Host Specificity.

\section{Adaptations of Glochidia Morphology}

\section{Attachment to gills ws skin}

Glochidia can attach to either gills or skin of the host, but attachment to skin and fins is more common for the triangular, hooked glochidia of Unioninae and Hyriidae (Lefevre and Curtis 1912, Wood 1974, Wächtler et al. 2001). Most hooked glochidia are

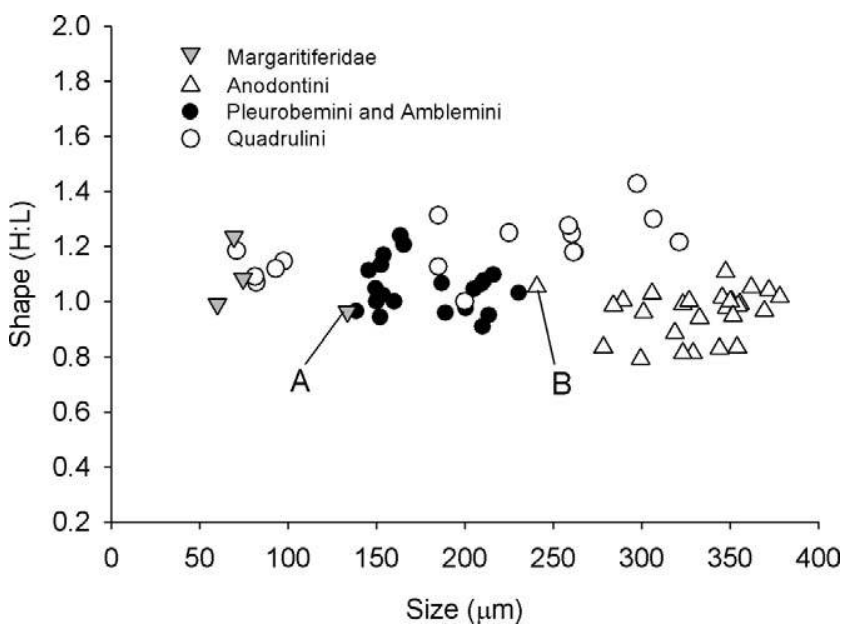

FIG. 2. Glochidia shape (shell height:length ratio [H:L]) and size (mean of shell length and height) in Margaritiferidae, Anodontini, Pleurobemini, and Quadrulini. A = Margaritifera auricularia, $\mathrm{B}=$ Simpsonaias ambigua. See Appendix for data and references.

relatively large and dorsoventrally short (low height: length ratio [H:L]; Fig. 2), and these traits improve leverage and gripping force (Hoggarth and Gaunt 1988, Bauer 1994). They bear hooks on the ventral apices of the valves that might facilitate attachment to skin. The morphology of the hooks in Unioninae and Hyriidae differs, and the hooked glochidia of Unioninae might be secondarily derived from an unhooked ancestor (Ortmann 1921, Graf and Cummings 2006). In some studies of natural infections, hooked glochidia attached primarily to skin (Dartnall and Walkey 1979, Dudgeon and Morton 1984, Jansen 1991, Martel and Lauzon-Guay 2005). However, in other studies, they attached primarily to gills (Atkins 1979, Threlfall 1986, Weiss and Layzer 1995) or the proportion varied depending on mussel or host species (Giusti et al. 1975, Blaẑek and Gelnar 2006).

Glochidia of Margaritiferidae and most Ambleminae attach primarily to gills, which provide a large surface area of soft tissue and a minimal mucus layer. These glochidia are typically smaller and taller in shape than those of Unioninae (Figs 2, 3), and they usually have a rounded ventral margin that lacks midventral hooks (Young and Williams 1984b, Bauer 1994). At least 3 species of Elliptio (Pleurobemini) have small, triangular glochidia with hooked ventral margins (Coker et al. 1921, O'Brien et al. 2003). We do not know if triangular glochidia in these species are associated with attachment to skin.

Larval threads in some form are often present in skin- or fin-parasitic Unionoid larvae, including 


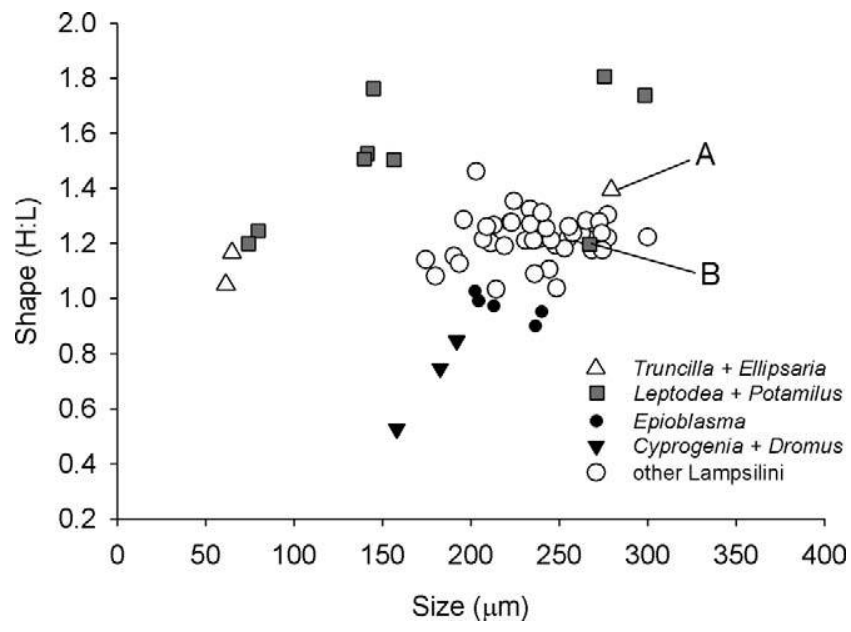

FIG. 3. Glochidia shape (shell height:length ratio [H:L]) and size (mean of shell length and height) in Lampsilini. A = Ellipsaria lineolata, B = Leptodea ochracea. See Appendix for data and references.

species of Mycetopodidae (Fryer 1961, Parodiz and Bonetto 1963), Hyriidae (Parodiz and Bonetto 1963), and Unioninae (e.g., Lefevre and Curtis 1912, Jansen et al. 2001). Threads are thought to facilitate suspension of glochidia in the water column or from aquatic vegetation and increase the chance of contact with the host by catching on and adhering to fins and skin (Howard 1914, Fryer 1961, Wood 1974). The filtering action of gills might make threads unnecessary to gain close contact and attachment for gill-parasitic glochidia. Larval threads are apparently absent in glochidia of most Ambleminae but are present in Fusconaia flava, Megalonaias nervosa, Amblema plicata, Plethobasus cyphyus (Lefevre and Curtis 1912, Howard 1914, Coker et al. 1921), and Popenaias popeii (Carman 2007). Threads are also present in Elliptio dilatata (Coker et al. 1921), Elliptio complanata (Lillie 1895, Lefevre and Curtis 1912, but see Matteson 1948), and Elliptoideus sloatianus (O'Brien and Williams 2002). Among these species, attachment and encapsulation on skin as well as gills have been noted for Megalonaias nervosa (Howard 1914) and P. popeii (Carman 2007).

More experimental study is needed to determine whether the use of gills or skin requires different physiological adaptations, as opposed to delivery and attachment mechanisms. Glochidia of Anodonta cataracta attached to gills were sloughed, whereas glochidia on other surfaces persisted (Lefevre and Curtis 1912). Conversely, glochidia of E. complanata attached to both skin and gills, but those on skin were unlikely to persist (Matteson 1948).

\section{Miniature glochidia}

Exceptionally small or miniaturized glochidia, i.e., $\sim 60$ to $100 \mu \mathrm{m}$, appear in Margaritiferidae and within 3 clades of Unionidae using molluscivorous hosts (Appendix, Figs 2, 3). Among the Lampsilini, Leptodea + Potamilus (Roe and Lydeard 1998) and Truncilla + Ellipsaria (Campbell et al. 2005) use molluscivorous freshwater drum (Aplodinotus grunniens) as host (Surber 1912, 1913, Wilson 1916, Roe et al. 1997). Leptodea have miniature glochidia (Fig. 3) except $L$. ochracea, the host of which is unknown (Nedeau et al. 2000) but is not $A$. grunniens, given that their ranges do not overlap. The phylogenetic position of $L$. ochracea has been questioned based on morphology (Smith 2000) and genetic evidence (D. Zanatta, Trent University, personal communication). Potamilus glochidia are larger but uniquely shaped (discussed later). Truncilla glochidia are miniature, but those of Ellipsaria lineolata are not (Fig. 3). In Quadrulini, members of the Quadrula quadrula species group have exceptionally small glochidia (Fig. 2). This clade includes Quadrula apiculata, Quadrula rumphiana, Quadrula quadrula, Quadrula fragosa (Serb et al. 2003), and Quadrula (=Tritogonia) verrucosa (J. Serb, Iowa State University, personal communication), which use molluscivorous catfish (Ictaluridae) hosts (Howard 1914, Kurth and Hove 1997, Steingraber et al. 2007). Other species of Quadrulini use ictalurid or cyprinid hosts and have larger glochidia (Howard 1914, Hove 1997, Yeager and Neves 1986). Anodontini have relatively large glochidia, but that of Simpsonaias ambigua is the smallest in the tribe (Fig. 2). Howard (1951) suggested that the host, the aquatic salamander Necturus, feeds on Simpsonaias, but direct observations of feeding were not reported.

Miniaturized glochidia appear to have arisen several times within clades that use molluscivorous hosts. We hypothesize that these mussels might attract the host and thereby incur an increased risk of predation and shortened life span relative to other mussel species. These factors could select for early maturation and production of a maximal number of minimally sized offspring. Such trends are generally expected in organisms with short or unpredictable life expectancy (Pianka 1970). Presumably more glochidia can be produced with the same energetic investment if the glochidia are small (Bauer 1994). Assuming similar shape, geometry indicates that a $60-\mu \mathrm{m}$ glochidium has only $1.6 \%$ the volume of a $240-\mu \mathrm{m}$ glochidium.

The $4^{\text {th }}$ clade with exceptionally small glochidia, Margaritiferidae, is not associated with molluscivorous hosts. The glochidia of most Margaritifera species are thought to drift in the water column and attach to the gills of salmonids (Murphy 1942, Young and 
Williams 1984a, b). Hypothetically, this strategy might favor small glochidia for 2 reasons. First, the low probability of individual glochidia encountering a host via broadcast might favor very small glochidia as a mechanism for increasing the number of offspring that can be produced (Bauer 1994). Second, small size enhances suspension in the water column, which is presumably important for species that broadcast glochidia to pelagic hosts. Some glochidia use threads for suspension, but threads appear to be lacking in Margaritiferidae. Sediment particles tend to remain suspended in rivers if their diameter is $<\sim 65 \mu \mathrm{m}$ (Waters 1995), which is near the size of the smallest glochidia (Figs 2, 3). The glochidium of Margaritifera auricularia, at $135 \mu \mathrm{m}$, is larger than other margaritiferids, and this species apparently uses sturgeon (Acipenser sp.) and possibly river blenny (Salaria fluviatilis) as hosts (Araujo et al. 2001, 2002, López et al. 2007). We hypothesize that the larger glochidium of $M$. auricularia might have been favored because deposition rather than suspension enhances contact of the glochidia with benthic-feeding hosts.

\section{Growth during encapsulation}

Most glochidia do not grow during encapsulation (Lefevre and Curtis 1912). However, it appears that all glochidia $<100 \mu \mathrm{m}$ grow substantially (i.e., $>2$-fold in length) before leaving the host. Glochidia of Margaritifera falcata grow from 60 to $420 \mu \mathrm{m}$ (Murphy 1942), and those of Margaritifera margaritifera grow from 70 to $390 \mu \mathrm{m}$ during encapsulation (Young and Williams 1984b). The larger glochidium of M. auricularia grows less, from 135 to $210 \mu \mathrm{m}$, before leaving the host (Araujo and Ramos 2001, Araujo et al. 2002). The small glochidia of Q. quadrula (Howard and Anson 1922) and $Q$. fragosa (Steingraber et al. 2007) grow substantially during encapsulation, but the larger glochidia of Quadrula cylindrica, Quadrula metaneora, and Quadrula pustulosa do not (MCB, WRH, and WNR, personal observations). In Lampsilini, growth during encapsulation has been reported in the glochidia of Lampsilis fragilis, Potamilus alatus, Potamilus ohiensis, Truncilla donaciformis, Truncilla truncata (Howard 1914, Coker and Surber 1911, Surber 1912, Howard and Anson 1922), Potamilus inflatus (Roe et al. 1997), Potamilus capax (Cummings and Mayer 1993), and Leptodea leptodon (Barnhart 2001). These species each have either very small glochidia (Leptodea, Truncilla) or axe-shape glochidia (Potamilus, see following).

The apparently convergent evolution of growth during encapsulation in 4 clades with miniaturized glochidia (Margaritiferidae, Q. quadrula species group, Leptodea, and Truncilla) suggests that the lower limit of juvenile size is strongly related to survival. Small size favors suspension, and we hypothesize that juveniles $<150 \mu \mathrm{m}$ might have difficulty settling in flowing water following release from the host. The relationships among juvenile size, current speed, and settlement deserve study, given evidence that flow strongly affects mussel recruitment (e.g., Howard and Cuffey 2006, Morales et al. 2006).

\section{Tall and short glochidia}

The unusual tall shape and very short hinge of Potamilus glochidia (H:L $\geq 1.5$; Fig. 2 ) are well known but unexplained. Growth during encapsulation appears to be characteristic of all Potamilus species, regardless of size. During encapsulation, anteriorposterior growth exceeds dorsal-ventral growth so that the axe-shape is lost (Howard 1914, Coker et al. 1921). This growth might be necessary because the peculiar shape of the glochidium prevents closing at the lateral margins and would be incompatible with a defensive role for the shell in the juvenile stage.

Among Lampsilini, unusually short glochidia (H:L $\leq 1$; Fig. 3) appear in Cyprogenia + Dromus and Epioblasma. Host infection strategies of these 2 clades differ drastically (conglutinates vs host capture; see Host Infection Strategies). However, Hoggarth and Gaunt (1988) suggested that small glochidia with very effective delivery devices are prepositioned for initial attachment and, therefore, have less need for large gape, so they might instead emphasize leverage and force of attachment. Larger, morphologically short glochidia that require leverage and force to attach to skin also are found in Anodontini. The host capture strategy of Epioblasma (see Epioblasma: host trapping) can result in large numbers of glochidia attaching to skin and fins, although it has not yet been shown that these glochidia are able to encapsulate and transform when attached to skin.

\section{Host Infection Strategies}

\section{Broadcast of free larvae}

Here we define broadcast as release of brood from the female without adaptations to attract host fish to the female mussel. Broadcast of free larvae (i.e., free of the egg membrane) appears to be typical of mainly fin- or skin-parasitic species, including most Unioninae (Lefevre and Curtis 1912, Aldridge and McIvor 2003), and M. nervosa (Quadrulini) (Howard 1914, Howard and Anson 1922, Woody and Holland-Bartels 1993). Some gill-parasitic species also are thought to contact the host mainly as free glochidia. These include the Margaritiferidae (e.g., Murphy 1942, Young and 
Williams 1984a, b), and certain Ambleminae, including A. plicata (Coker et al. 1921), Amblema neislerii (O'Brien and Williams 2002), E. complanata (Mattesson 1948), Elliptio arca (Haag and Warren 2003), and E. sloatianus (O'Brien and Williams 2002). The glochidia are released in fragile conglutinates that break up to release the glochidia, or the glochidia could be suspended initially in mucus, which might aid suspension and limit dilution in the water column. As discussed already, larval threads or small size also might enhance suspension. Broadcast of free glochidia can be effective if host fish are abundant, but only very small proportions of the glochidia are likely to encounter a host (Jansen et al. 2001). An interesting modification of simple broadcast is the behavior of Unio crassus, which moves into shallows and spurts a stream of water with glochidia that spatters on the surface and, presumably, attracts host fish (Vicentini 2005).

Free glochidia of many species of Ambleminae appear in drift (Neves and Widlak 1988, Jirka and Neves 1992). However, many species that occur in drift are known to use specialized host infection strategies, and the relative contribution of drift to host infection in these species is unknown. This question is significant in the context of toxicology. Glochidia survive in the water for periods ranging from hours to weeks, depending on species and temperature (e.g., Zimmerman and Neves 2001, Ingersoll et al. 2006, Akiyama and Iwakuma 2007), but the typical exposure time in water before encountering hosts in nature is unknown. Therefore, exposure times for testing the effects of toxicants on glochidia in water are generally based on the duration of control survival (ASTM 2005, Cope et al. 2008).

\section{Conglutinate strategies}

A key adaptation contributing to the success of many Ambleminae is the production of conglutinates. Conglutinates are defined as aggregates of eggs, formed as molds in the water tubes of the female demibranch (Lefevre and Curtis 1912). These structures were termed "placentulae" by Ortmann (1911), but that term was rejected by Lefevre and Curtis (1912) because it implied a nutritive function. Conglutinates also have been called "ovisacs" (e.g., Matteson 1948, Barnhart and Roberts 1997), but that term also is used to refer to the gravid water tubes of the marsupial demibranches in Lampsilini and Anodontini (Ortmann 1911) and might better be reserved for that usage. Host fish attempt to feed on conglutinates, thereby freeing the glochidia and bringing them into contact with the host gills. Conglutinates improve the probability of host contact and can target particular feeding guilds of host species. Mussels that produce conglutinates typically produce many fewer glochidia than species that broadcast glochidia, providing clear evidence that these structures enhance the probability of successfully infecting fish hosts (Haag and Staton 2003). Conglutinates also might protect the glochidia, possibly prolonging the infective period after release from the female, but we are not aware of any data testing this hypothesis. More information is needed on survival time within conglutinates and on the role that conglutinates might play in protection from toxicants.

Some conglutinates are artifacts of premature release of the brood from the female. The membranes of the eggs typically adhere to one another, and this probably helps to prevent loss of eggs from the marsupial water tubes during brooding. In species that lack functional conglutinates, the egg membranes weaken or disintegrate during development to free the larvae (Matteson 1948, Schwartz and Dimock 2001). However, even these species might abort the brood prematurely in solid conglutinates in response to stress (e.g., Lefevre and Curtis 1912, Araujo and Ramos 1998, Aldridge and McIvor 2003, Haag and Warren 2003). We will refer to these artifacts as puerile conglutinates to distinguish them from functional conglutinates, which are durable and contain mature glochidia and, therefore, could function to infect host fish. Functional conglutinates are found mainly in Pleurobemini and Lampsilini and are generally lacking or, at least, unreported in other Unionoida (Table 1). Conglutinates reported for Australian hyriids (Walker et al. 2001) were clumps of free glochidia entangled by larval threads rather than aggregated eggs (K. F. Walker, University of Adelaide, personal communication).

Conglutinates are molded in the interlamellar spaces in the marsupial demibranch. In Unionidae, the interlamellar space is divided into vertical water tubes by interlamellar septa, so that the internal space roughly resembles a comb, with the epibranchial passage as the back of the comb and the water tubes as the teeth. In Margaritiferidae, septa are lacking, and the brood is released as a few asymmetrical masses of fragile conglutinate that break up readily (Murphy 1942). In contrast, species with septa and well-defined water tubes can potentially produce discrete, uniformly shaped conglutinates. The marsupial demibranches of females exhibit a larger number of more closely spaced septa than the nonmarsupial female demibranches or male demibranches. These "crowded septa" were suggested to reinforce the gill during brooding, limiting the degree of distention (Ortmann 1911, pp. 290-292). However, the number of septa also can determine the number of conglutinates produced (excepting Strophi- 
TABLE 1. Taxonomic occurrence and types of conglutinates. Conglutinates are cohesive or enveloped masses of eggs, formed as molds in the female demibranches. Puerile conglutinates consist of immature eggs released prematurely (aborted) in response to stress. Functional conglutinates contain mature glochidia and presumably function to attract fish and infect them with glochidia. Dimensions of conglutinates (in reference to the demibranch) are length (dorsoventral), width (lateral), and thickness (anteroposterior).

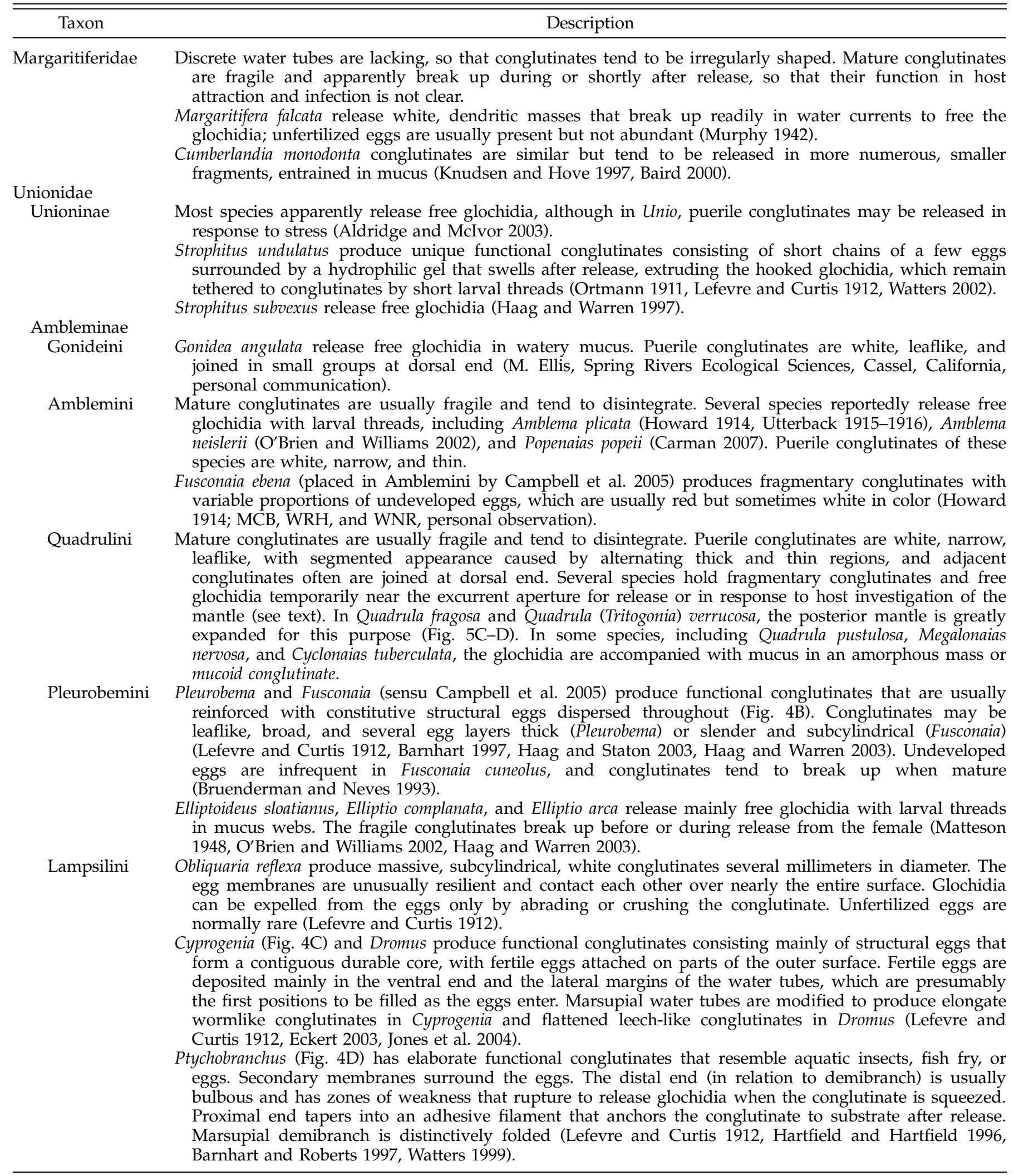


TABle 1. Continued.

\begin{tabular}{|c|c|}
\hline Taxon & Description \\
\hline Lampsilini & $\begin{array}{l}\text { Lampsilini using mantle lures and host extraction, including Lampsilis, Ligumia, Venustaconcha, and Villosa, } \\
\text { also can expel fragile conglutinates that are white, leaflike, broad, and several egg layers thick, and that } \\
\text { break up readily (Fig. 4A) (e.g., Lefevre and Curtis 1912, Allen et al. 2007). We have observed similar } \\
\text { fragile conglutinates from Actinonaias ligamentina and Potamilus alatus (MCB, WRH, and WNR, personal } \\
\text { observations). }\end{array}$ \\
\hline
\end{tabular}

tus, which is a special case). If the eggs occupy only the water tubes, the mold from each tube is separate. If the eggs also occupy part of the epibranchial chamber, then the molds tend to be joined dorsally and might be released in pairs or larger groups.

The simplest mechanism for holding eggs together in conglutinates is persistence of the cohesive egg membranes as the glochidia mature. Such cohesive conglutinates could evolve from puerile conglutinates by changes that inhibited the dissolution of the egg membranes. In cohesive conglutinates, a functional tradeoff is evident between conglutinate durability and the ease with which the glochidia can be dislodged from the eggs. For example, Lampsilis releases fragile conglutinates that break up readily and probably serve only as a secondary means for infecting hosts (Fig. 4A). At the other extreme, Obliquaria releases remarkably tough cohesive conglutinates from which the glochidia can be dislodged only with difficulty (Lefevre and Curtis 1912), a puzzling
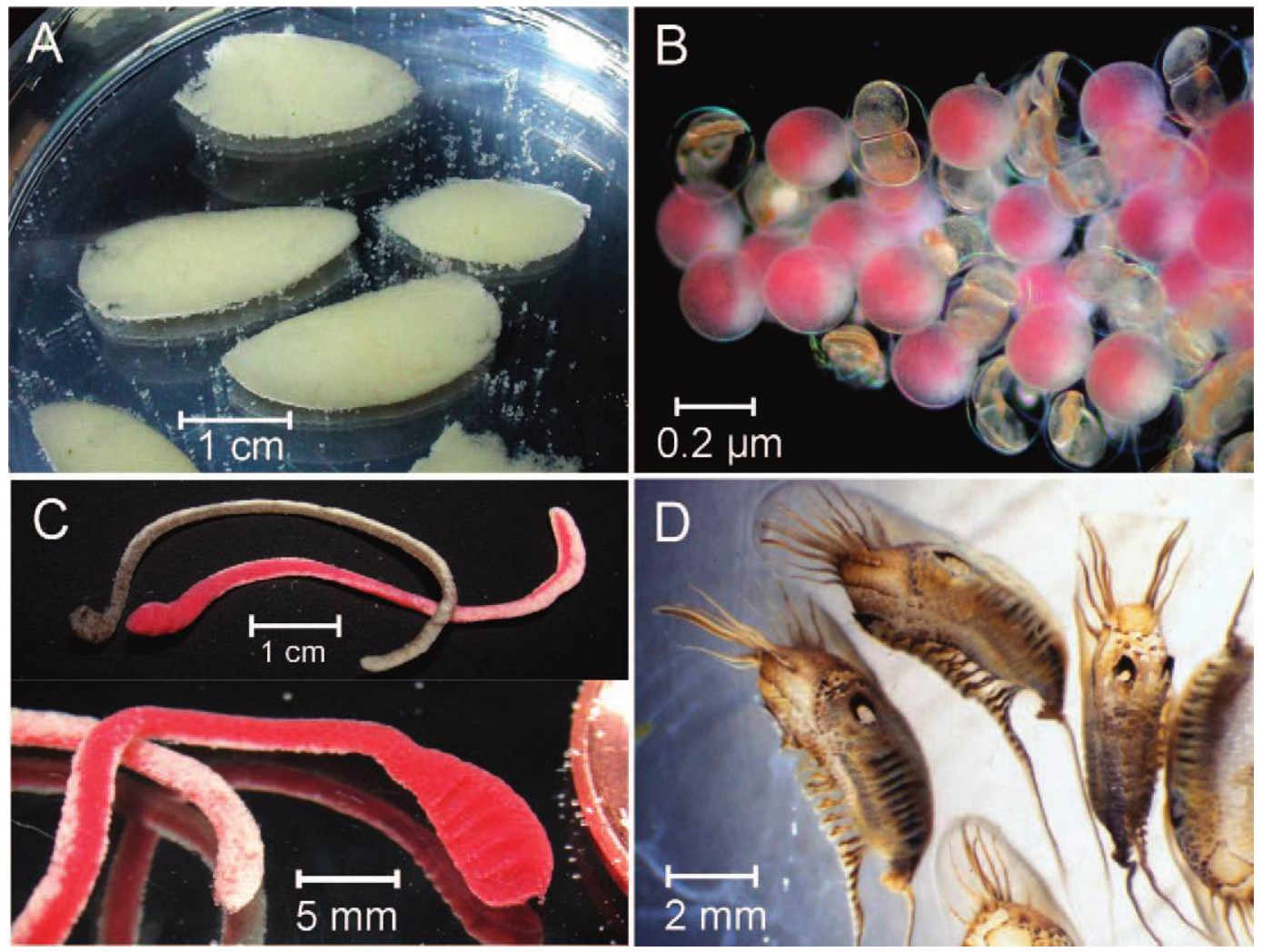

Fig. 4. Representative conglutinates. A.-Lampsilis cardium fragile conglutinates and loose glochidia. B.-Fusconaia flava conglutinate showing opaque structural eggs and clear fertile eggs containing glochidia. C.-Cyprogenia aberti conglutinates. Brown and red color morphs are shown. The "head" and core consist of pigmented structural eggs (dark); fertile eggs containing glochidia (pale) are on the sides and distal end. D.-Ptychobranchus subtentum conglutinates strongly resemble blackfly pupae (Simulidae). 

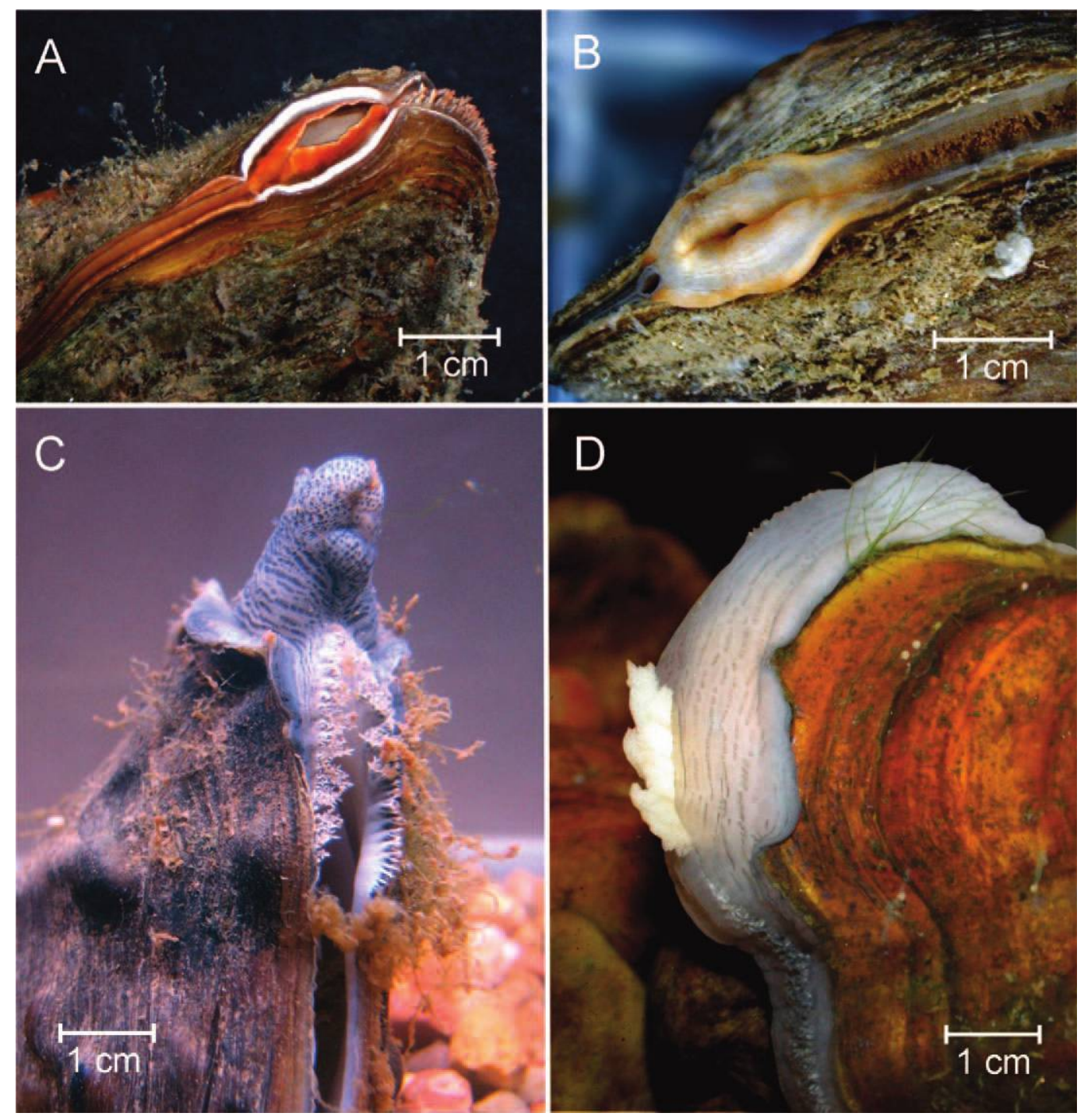

FIG. 5. Mantle modifications in Quadrulini. A.-Brooding female Quadrula cylindrica. White mantle edge surrounds excurrent aperture, which is orange. When the aperture is touched, glochidia are ejected reflexively. Video is available (Unio Gallery, http:/ / unionid.missouristate.edu). B.-Brooding female Quadrula pustulosa. Small supra-anal opening appears at left of swollen mantle margin surrounding excurrent aperture. Compare with C and D. C.-Brooding female Quadrula fragosa showing the inflated mantle magazine (at top) and the papillose incurrent aperture. The elevated position and wide gape are characteristic. D.- Side view of Quadrula (Tritogonia) verrucosa showing the inflated mantle magazine. The mantle retracted slightly after being touched, revealing a white mass of conglutinates within.

feature that remains unexplained because the fish host is not known. Both the persistence of the egg membranes and the degree of contact among eggs affect the durability of the conglutinate.

Another mechanism for producing functional conglutinates is the formation of structural eggs (Barnhart 1997; Fig. 4B, C). The membranes of fertile eggs weaken during development, probably as a result of enzymes produced by the embryo, so that when the glochidium is fully developed, the membrane is easily ruptured. The structural eggs do not develop, so their membranes remain intact and hold the conglutinate together. Undeveloped eggs can result from incomplete fertilization, but some taxa apparently have mechanisms to produce structural eggs as a normal process. In these taxa, undeveloped eggs occur in large proportion or particular anatomical positions in conglutinates regardless of population density or other factors that might cause incomplete fertilization. We refer to these normally undeveloped eggs as constitutive structural eggs in contrast to unfertilized eggs that result from abnormal shortage of sperm or other 
factors. The eggs of these species are often brightly pigmented. The color is lost in eggs with mature glochidia but persists in the structural eggs, enhancing the visibility of conglutinates.

Structural eggs evidently evolved independently at least twice, in Cyprogenia + Dromus and in Pleurobema + Fusconaia (Barnhart 1997, Eckert 2003, Haag and Staton 2003, Haag and Warren 2003, Jones et al. 2004). Colored eggs also appear in other taxa, including $P$. cyphyus and "Fusconaia" ebena (Lefevre and Curtis 1912, Howard 1914); this phenomenon suggests that structural eggs also might be used by these taxa. The evolution of structural eggs is intriguing because of the quantifiable tradeoff with production of larvae. Each structural egg represents one fewer offspring, which must be offset by the increased probability of success of the remaining glochidia. It appears unlikely that structural eggs are determined by the genotype of the egg or zygote. A dominant allele that prevented development would immediately be lost. A recessive allele could prevent development in $25 \%$ of the offspring of 2 heterozygote parents, but no structural eggs would be produced if either parent lacked the allele. It appears more likely that the female controls production of the structural eggs, either by selective fertilization or by some cellular mechanism during oogenesis. We are not aware of any studies of these mechanisms.

At least 2 clades in Lampsilini (Ptychobranchus and Hamiota) developed sheathed conglutinates with welldefined outer layers. In Ptychobranchus, 3 layers of membranes surround the glochidia producing a complex delivery device (Watters 1999). These remarkable structures are variously shaped and marked to resemble fish or insect larvae, insect pupae, or fish eggs (Lefevre and Curtis 1912, Hartfield and Hartfield 1996, Barnhart and Roberts 1997, Watters 1999) (Fig. 4D). The female marsupial demibranch is folded to accommodate more septa and more conglutinates, as is recognized in the genus name. The shape and size of conglutinates depend on the anatomy of spaces in the female demibranches in which they are molded. In most cases, each water tube in the female demibranch produces one conglutinate. However, in Hamiota, conglutinates from all the water tubes in each demibranch are released simultaneously within a mucus sheath to form a tethered superconglutinate that resembles a swimming minnow (Haag et al. 1995, O’Brien and Brim Box 1999).

\section{Quadrulini: mantle storage and reflexive release}

Extrusion of conglutinates or glochidia from the ctenidia is too slow a process (Ortmann 1911, p. 306) to occur immediately in response to fish. However, in Quadrulini, glochidia and fragmentary conglutinates extruded from the ctenidia are stored in the mantle for periods of minutes to hours (MCB, personal observation), so that they can be rapidly discharged either by reflexive contraction of the mussel's valves or by attack of a host. In some Quadrula species, the mantle surrounding the excurrent aperture is expanded in brooding females (Kurth and Hove 1997, Heath et al. 1998). We refer to this expansion as a mantle magazine (Fr. magasin = storehouse) because it allows storage of a bolus of glochidia for reflexive release. The mantle expansion is small in Q. pustulosa and much larger in Q. fragosa and Q. verrucosa (Fig. 5B-D). In the field, we observed release of clumps of glochidia and mucus from Q. pustulosa and Cyclonaias tuberculata when the aperture was touched (MCB and WHH, personal observation). These species use ictalurid catfish as hosts. We have videotaped Ictalurus punctatus attacking the mantle magazine of $Q$. verrucosa, a behavior that supports the suggestion of Pepi and Hove (1997) that chemical attraction might be involved.

The Q. metanevra species group (Serb et al. 2003) uses mainly cyprinid hosts rather than ictalurids. This group includes Q. cylindrica (Yeager and Neves 1986, Fobian 2007), Quadrula intermedia (Yeager and Saylor 1995), and Q. metanevra (Crownhart et al. 2006). These species apparently do not exhibit large mantle magazines but instead attract sight-feeding minnows with visual lures, analogous to the mantle lures of Lampsilini. In brooding $Q$. cylindrica, the excurrent aperture is reddish-orange in color and encircled by a bright white ring (Fobian 2007) (Fig. 5A). The aperture of Q. metanevra is expanded, crenulated, and pale (M. Davis, B. Seitman, A. Crownhart, Minnesota Department of Natural Resources, personal communication). Both species abruptly eject small quantities of conglutinate fragments and free glochidia from the excurrent aperture in response to stimulation by vibration, touch, or shadows (Lefevre and Curtis 1910, Fobian 2007, A. Crownhart, Minnesota Department of Natural Resources, personal communication). This reflexive release is apparently possible because the glochidia are held temporarily in the mantle after release from the demibranches, as explained previously.

Reflexive release of brood in response to the approach of host fish might occur in other taxa, but few observations are available. An increased rate of glochidia release in the presence of host fish or hostfish scent was reported in Anodonta piscinalis (Jokela and Palokangas 1993). 


\section{Lampsilini: mantle lures and host extraction}

The highly developed mimetic mantle flaps of Lampsilini, including Lampsilis, Ligumia, Villosa, Toxolasma, and Venustaconcha are among the best known features of mussel biology, yet the realization that these structures act as host lures was remarkably slow to develop (Coker et al. 1921, Howard and Anson 1922, Welsh 1933, Kraemer 1970, Haag and Warren 1999). This delay was apparently caused by the curious hypothesis of Ortmann (1911, 1912), which stated that the mantle flaps and protrusion of the marsupium acted to provide $\mathrm{O}_{2}$ to the brood. The idea was given far more credence than it deserved (e.g., Kat 1984) and is refuted by several observations, including: 1) other unionids brood but lack these features, 2) lure display is not continuous during brooding, 3) water movement through the ctenidia depends on ciliary mechanisms rather than external water flow, and 4) Ortmann's hypothesis fails to explain the elaborate mimicry seen in these species. Mantle lures clearly attract and elicit attacks from host fish and result in transmittal of glochidia to the hosts (Haag and Warren 1999, 2000).

Early accounts generally suggested that mussels with mantle lures somehow released glochidia to the fish (e.g., Howard and Anson 1922, Kraemer 1970). In contrast, we find that attack by the host fish ruptures the marsupium and extracts glochidia. Videotaped attacks by host fish on Lampsilis and Villosa show this clearly (Fig. 6A-D; videos are available on the Unio Gallery, http://unionid.missouristate.edu). Several adaptations that facilitate host extraction of glochidia are evident in species with mantle lures. First, the marsupium is restricted to the posterior portion of the demibranches and is accommodated by the characteristically inflated female shell (Ortmann 1911, 1912). This arrangement positions the marsupia adjacent to the lure, where they can be struck by the host (Fig. 6B; see also figures in Lefevre and Curtis 1912, Kraemer 1970). Second, the marsupial gill is mobile and can be moved adjacent to the lure. In Lampsilis, one or both demibranches are typically protruded between the valves and the mantle flaps during lure display (Ortmann 1911, Kraemer 1970). Third, the marsupial demibranches are modified to permit the ventral edge to rupture. The lamellae can separate at the ventral edge, and the gap is bridged by a thin tissue that bulges out ventrally from each brooding water tube (ovisac). The bulging ends of the ovisacs are sometimes visible between the separated edges of the lamellae, and the spaces between them can be misinterpreted as pores (explained by Ortmann 1911, 1912). The ends of the ovisacs are closed, but they are easily ruptured. These specialized features and abundant observational evidence support the premise that host extraction is a primary mode of glochidia release in species with mantle lures.

Similar to conglutinates, mantle lure specializations are characteristic of particular taxa, often recognized as genera. For example, the genus Toxolasma is characterized by paired inflatable tubes (caruncles) that perform a slow twiddling motion while the ventral mantle margin performs a fast rippling movement (Call 1895, Schwegman 1998). Another potentially informative character appears in several species of Villosa, which have the behavior of anchoring the foot and rocking the body anterior and posterior while displaying the lure (Unio Gallery). However, it is difficult to align many lure characters with phylogeny because of a lack of sufficiently detailed comparisons of lure morphology and movements. Another confounding factor is lure polymorphism within species (see Polymorphism and frequency-dependent selection).

\section{Epioblasma: host trapping}

Use of host extraction led evolutionarily to a particularly dramatic infection strategy in the lampsiline genus Epioblasma-host capture by the female mussel. These small mussels use darters (Percidae) and sculpins (Cottidae) as hosts (e.g., Yeager and Saylor 1995). The brooding females gape the shell valves to expose the mantle. When a fish investigates and touches the mantle, the mussel clamps the shell valves on the fish to hold it. The female then expels glochidia while holding the fish captive. This behavior was apparently first witnessed by $R$. Sherman-Mulcrone (University of Michigan, personal communication), who captured Epioblasma triquetra clamped on the head of a Percina caprodes (log perch) in 2003. Other anecdotal observations of trapped fish and snapping behavior were reported by Jones et al. (2006). We (WNR and MCB) videotaped fish capture by $E$. triquetra in 2004 and more recently videotaped captures by Epioblasma torulosa rangiana, Epioblasma capsaeformis, and Epioblasma brevidens. These videos are available at the Unio Gallery web site and are the basis of the following descriptions.

Several specializations for host capture are evident in Epioblasma female anatomy and behavior. The posterior edge of the female shell is armed with recurved denticles (E. triquetra, E. brevidens, and $E$. capsaeformis) or a recurved edge (E. t. rangiana) that help to hold the host (Fig. 7A-C). The mantle of female Epioblasma exhibits a peculiar ridge with a spongy interior (Ortmann 1911). We suggest the term cymapallium for this inflatable structure (Gr. kyma =a wave or 

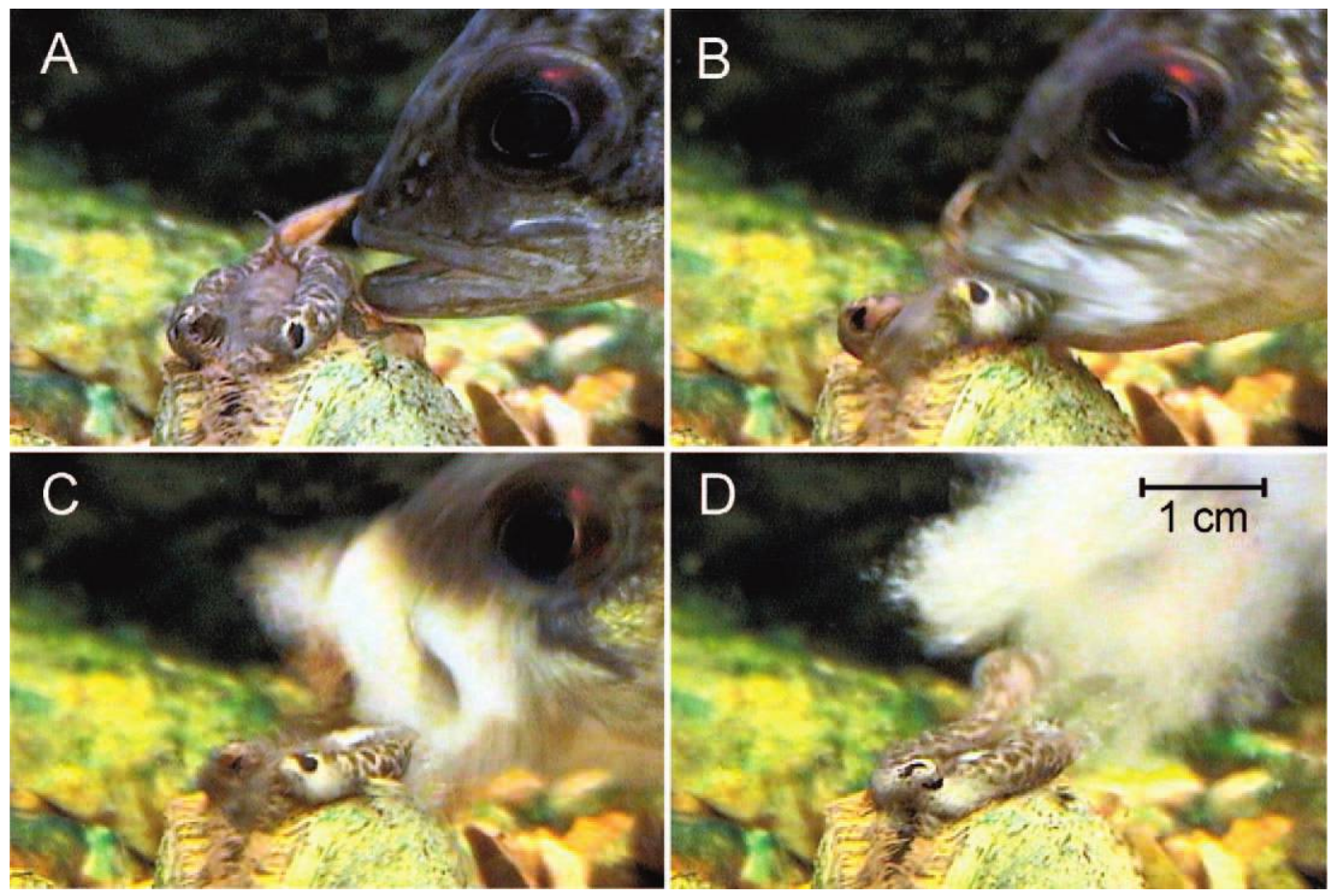

FIG. 6. Glochidia extraction by fish host (Ambloplites constellatus) from Lampsilis reeveiana. The fish approaches (A) and bites the lure (B), then abruptly opens its mouth and expands its buccal cavity to inhale the "minnow" (C). Suction created by the fish ruptures the marsupium and extracts a cloud of glochidia $(C, D)$. Note that the valves of the mussel do not close (compare valve position in panels $\mathrm{C}$ and $\mathrm{D})$. These observations indicate that glochidia are extracted by the host rather than ejected by the mussel. Video is available (Unio Gallery, http://unionid.missouristate.edu).

swelling; L. pallium = a mantle or cover). In E. triquetra and $E$. brevidens, the cymapallium inflates to form a gasket-like seal around the head of the captured fish and reduces leakage of glochidia. In E. torulosa, E. florentina, and E. capsaeformis, the cymapallium is broadly expanded into mantle pads that line the expanded posterior regions of the female shell (Fig. 7D).

Mantle lures are variously developed in Epioblasma. Epioblasma capsaeformis and Epioblasma florentina walkeri possess mobile microlures on the mantle edge just anterior of the excurrent aperture (Jones et al. 2006), whereas E. t. rangiana has an immobile tuft of papillae at this position (Fig. 7D). The mantle of E. triquetra bears a short series of ridges, and E. brevidens exhibits 2 to 4 small vesicles that resemble fish eggs adjacent to a group of short papillae (Fig. 7C). These structures appear to be suited to attract host fish. In most populations of E. capsaeformis (Jones et al. 2006) and E. t. rangiana, the mantle pads are pale and highly reflective, perhaps acting as an attractant.

Brooding female Epioblasma restored original wording emerge from the substrate, assume a headstand posture, and gape the valves (Fig. 7C, D). It is significant that displaying females are unresponsive to minor disturbance, such as tapping on the shell or even being moved, unless the mantle is contacted. When the mantle is touched the valves snap shut, closing within $0.1 \mathrm{~s}$ in E. triquetra (judged from videoframe rate). In E. triquetra and E. brevidens, the gape is relatively narrow, $<1 / 4$ of the total width of the shell. In laboratory observations of these species, fish were usually caught by the head, in front of the eyes (Fig. 7B). In contrast, E. t. rangiana, E. capsaeformis, and E. f. walkeri gape very widely ( $>1 / 2$ of the total width) and usually captured fish behind the head, sometimes even enclosing entire small fish within the shell. When mussels missed, the valves reopened within 3 to $5 \mathrm{~min}$. When fish were captured, the valves remain clamped for up to $30 \mathrm{~min}$, generally relaxing only when the fish ceased struggling.

During capture, the apertures closed, the cymapallium inflated, and free glochidia were expelled within the mantle cavity. Glochidia expulsion apparently proceeds via the dorsal passages rather than rupture of the gill, and expulsion can be stimulated by allowing the mussel to clamp a severed fish head. A fish head with a siphon tube inserted through the mouth has proven useful for removing glochidia from Epioblasma for captive propagation (Unio Gallery, 

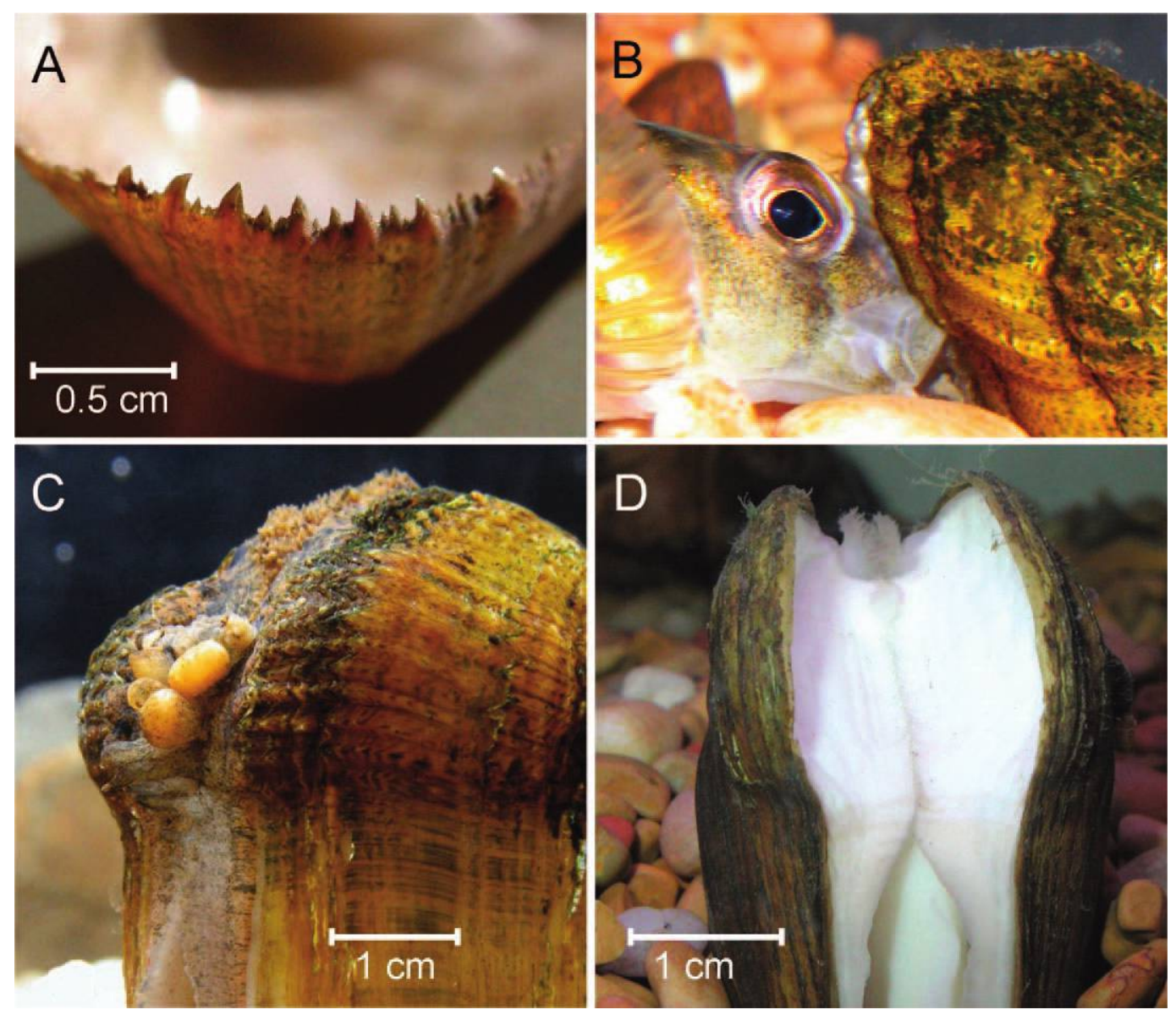

FIG. 7. Adaptations for host capture in Epioblasma. A.-Posterior of female shell of Epioblasma triquetra showing recurved denticles that hold captured host fish. B.-Percina caprodes captured by female E. triquetra. C.-Epioblasma brevidens brooding female displaying "fish egg" mantle lure. Note the toothed shell margins, similar to E. triquetra, adjacent to the lure. D.-Epioblasma torulosa rangiana brooding female displaying white mantle pads. Wide gape and elevated posture facilitate host fish capture. Video of host capture is available (Unio Gallery, http:// unionid.missouristate.edu).

http://unionid.missouristate.edu). In E. triquetra and E. brevidens, rhythmic contractions of the adductors forced water and glochidia through the mouth of the captured fish, so that glochidia were expelled directly through the gill cavities. In E. $t$. rangiana and $E$. triquetra, bellows movements also were observed, but the head and gill opercula of the fish typically were completely enclosed, and the expulsion of the glochidia was mainly into the mantle cavity. The mantle pads in these species cushion and apparently subdue the fish through asphyxia.

In our laboratory observations, fish captured by Epioblasma often died either during capture or within a few days after. The heads of captured Etheostoma were crushed by E. triquetra and E. brevidens. Percina caprodes has a sturdier skull and was more likely to survive. The frontal bones of $P$. caprodes are broader and the lateral ethmoids and mesethmoids are more robust than in Etheostoma sp. (figures in Norris 2001). These features are presumably adaptations to the habit of turning stones with the head to forage. Fish capture by E.t. rangiana and E. capsaeformis was also traumatic. In the Alleghany River, one of us (WNR) observed several dead Etheostoma associated with E. t. rangiana in the field, and they had noticeable crimp marks. Dead fish are of no use as hosts because attached glochidia will not transform. However, we suspect that the captured fish might not be the only fish that become infected with glochidia. Epioblasma species release large numbers of glochidia during each capture, and many of these are spilled and dispersed by the struggles of the captured fish. In aquaria, other fish were attracted by the struggle and sometimes picked at the captive. We hypothesize that the captured fish might act as a lure for other hosts that are infected incidentally. 


\section{Polymorphism and frequency-dependent selection}

Mantle lures and conglutinates are frequently polymorphic in mussel populations. Lampsilis fasciola exhibits 3 distinct lure morphologies within populations (Morris 2006, Zanatta et al. 2007). Mantle pad color is apparently polymorphic in some populations of E. capsaeformis (Jones et al. 2006). Conglutinate color varies among females in Cyprogenia aberti (brown or red; Fig. 4C; Eckert 2003), Fusconaia flava, F. ozarkensis, F. cerina (red or white; Barnhart 1997, Haag and Warren 2003), and Pleurobema decisum (orange or white; Haag and Warren 2003). Conglutinate shape and coloration differ among females within a population of Ptychobranchus greeni, resembling either larval fish or fish eggs (Hartfield and Hartfield 1996, Haag and Warren 1997). Genetic evidence is needed to determine whether these phenotypic variations are polymorphisms within species or represent separate species (Serb 2006, Zanatta et al. 2007, Serb and Barnhart 2008).

Maintenance of genetically based polymorphism in mantle lures and conglutinates within species could be the result of negative frequency-dependent selection by host fish (cf. Endler 1988). Fish often show signs of distress when glochidia attach (Haag and Warren 1999), and centrarchids in aquaria quickly learn to avoid conglutinates of Fusconaia and the mantle flap lures of Lampsilis. However, fish that have learned to avoid one lure morph might still be fooled by another, a principle well known to anglers. Therefore, a relatively rare form or color might have a selective advantage, which could preserve polymorphism in the population. Behavioral studies might be used to test this hypothesis.

\section{Evolutionary transitions in host infection mechanisms}

It seems likely that host attraction to the brooding female, perhaps by conglutinate release, preceded and facilitated the evolution of lures and host extraction. The reflexive release and mantle modifications seen in $Q$. metanevra and Q. cylindrica provide an analogy for the development of mantle lures. Possibly the ancestor of the luring lampsilines behaved similarly. After host attraction was established, adaptations that favored host extraction would have been more likely to evolve. Cladistic analyses based on gene trees place several taxa that apparently lack mantle lures near the base of the Lampsilini, including Obliquaria, Cyrtonaias, Glebula, and Plectomerus (Campbell et al. 2005, Zanatta and Murphy 2006). Apart from Obliquaria, the host infection strategies of these taxa have apparently not been described. It is equivocal whether their lureless condition is primitive or derived. Toxolasma and
"Villosa" fabalis, which have mantle lures, also appear to be primitive in these analyses (Zanatta and Murphy 2006).

Species that display mantle lures typically also release fragile conglutinates that break up readily. Examples include Lampsilis (Wilson and Clark 1912, Howard and Anson 1922, Kraemer 1970; Fig. 4A), Venustaconcha ellipsiformis (Allen et al. 2007), Ligumia recta, and Villosa iris (MCB, WRH, and WNR, personal observation). Release can occur at any time after the brood matures but is particularly likely late in the brooding season, probably because the marsupia must be emptied eventually to make room for new brood. Mussels that both display mantle lures and release conglutinates potentially could contact a wide range of hosts, a possibility that is consistent with observations that some species are able to transform both on predatory fish and on small-bodied taxa that appear unlikely to attack a mantle lure.

The clearest example of a bimodal infection strategy is in Hamiota, which is closely related to Lampsilis (Campbell et al. 2005, Roe and Hartfield 2005). Hamiota species are known for their superconglutinates (Haag et al. 1995, O'Brien and Brim Box 1999, Blalock-Herod et al. 2002; Table 1), but they also display mantle lures prior to conglutinate release. The mantle lures of Hamiota australis, Hamiota perovalis, and Hamiota subangulata are reduced (Hartfield and Butler 1997, Roe and Hartfield 2005), but the lure of Hamiota altilis resembles the elaborate mimetic lures of Lampsilis (Haag et al. 1999). Glochidia are easily extracted from the edges of the marsupia of $H$. subangulata by gentle suction (MCB, personal observation), consistent with use of host extraction similar to Lampsilis.

The apparent reduction or loss of mantle flap lures is evident in some higher lampsiline clades (Zanatta and Murphy 2006). Leptodea + Potamilus and Truncilla + Ellipsaria lack conspicuous mantle lures and use the molluscivore $A$. grunniens as host. The mode of host infection is not well understood in these taxa, but it probably includes predation by the host on smaller brooding females (Coker et al. 1921, Howard and Anson 1922). Such predation could be a primary mode of host infection in species with small females, such as L. leptodon (Barnhart 2001). Although they lack obvious mantle lures, both Ellipsaria and T. truncata respond to shadows and touch by flipping the mantle margin back and exposing the marsupia (M. Davis, Minnesota Department of Natural Resources, personal communication). This behavior presumably facilitates host extraction of glochidia. Mimetic elaborations of the mantle edge might simply be unnecessary to attract a host that seeks bivalves as prey.

The genus Actinonaias appears to be polyphyletic 
within a paraphyletic Lampsilis (Campbell et al. 2005, Zanatta and Murphy 2006). Actinonaias ligamentina and Actinonaias pectorosa lack mantle lures and release fragile conglutinates (N. Eckert, Virginia Department of Game and Inland Fisheries, personal communication; MCB, WRH, and WNR, personal observation). Gene trees indicate that $A$. ligamentina is most closely related to Lampsilis siliquoidea and that $A$. pectorosa is closest to either Lampsilis ornata (Campbell et al. 2005) or L. fasciola (Zanatta and Murphy 2006). It appears that A. ligamentina and A. pectorosa have independently lost the mantle flap lure and reverted to releasing conglutinates or free glochidia rather than relying on host extraction from the marsupium.

Adaptations for parasitism provide a rich source of phenotypic characters to complement molecular data and might help to resolve phylogeny (Zanatta and Murphy 2006). However, many of these characters are complex and might need to be broken down to be informative. The definition of lure- and conglutinaterelated characters for phylogenetic analysis should proceed carefully because of probable homoplasy. In Zanatta and Murphy (2006), "active host attraction strategy" equates to mantle flaps and conglutinates moved by water currents, which we do not see as homologous features. Moreover, in Zanatta and Murphy (2006), the character "complex conglutinates" equates the conglutinates of Ptychobranchus to those of Cyprogenia + Dromus, which clearly are not homologous in the "complex" aspects of their structures (membranes and structural eggs, respectively).

\section{Host extraction of glochidia and long-term brooding}

Most Pleurobemini, Quadrulini, and Amblemini release the glochidia during a brief period soon after the glochidia mature. In contrast, most Lampsilini and Anodontini brood mature larvae for several months over the winter, rather than releasing them immediately. These patterns have been termed short-term brooding (tachytictia) and long-term brooding (bradytictia) (Ortmann 1911, Graf 1997). Bradytictia evolved independently in Lampsilini and Anodontini, which both have mainly north-temperate distributions, and it has been interpreted as an adaptation to the shorter growing season at higher latitudes. Glochidia that are brooded over winter or that attach to the host over winter (Watters and O'Dee 2000) can metamorphose early in the spring. This strategy generally allows bradytictic taxa more time than tachytictic taxa for growth of the juvenile stage before the following winter (Ortmann 1911, Graf 1997, Graf and Ó Foighil 2000). Bradytictic species were the first to recolonize northern rivers in postglacial times (Graf 1997).
Dispersal of lentic anodontines into sloughs and oxbow lakes might be facilitated by infestation of the hosts in the early spring, so that glochidia are encysted when spring flooding occurs and disperses the host fish (Roberts and Barnhart 1999). Beyond the general patterns, the timing of spawning, the period of brooding, the timing of release of brood, and the number of broods exhibit considerable diversity within and among species and among geographic localities and are deserving of much more study (Heard 1998, Watters and O'Dee 2000, Haggerty et al. 2005).

We suggest that long-term brooding in Lampsilini might have arisen in conjunction with the evolution of mantle lures and host extraction of glochidia. Longterm brooding and host extraction allow lure-displaying species to reproduce successfully even when host population density is low and encounters are infrequent (Haag and Warren 1998). Other mussels must expel the brood from the demibranches for the glochidia to encounter the host fish. In contrast, mussels using host extraction can wait for the host to come and get the brood, rather than releasing it. Therefore, prolongation of the brooding and luring period will increase the probability of host encounter. Thus, host extraction provides a selective advantage to prolongation of the brooding period and could thereby lead to bradytictia. Host extraction of glochidia and infection could occur at any time but are presumably most likely when hosts are actively feeding. Mantle lures often are displayed beginning in autumn and sporadically even in winter. Lampsiline glochidia are present in drift nearly year-round but are most abundant in spring and summer (Zale and Neves 1982, Neves and Widlak 1988, Watters and O'Dee 2000). Most females of luredisplaying species are still fully charged in early spring and typically retain at least part of the brood well into the following summer, and partly charged females become increasingly frequent later in the season. All females presumably discharge the remaining brood prior to the next round of spawning.

What of correlation between bradytictia and reproductive strategy within Lampsilini? Of the lampsilines that appear to be primitive (Campbell et al. 2005, Zanatta and Murphy 2006), Toxolasma species bear mantle lures, and they generally are regarded as bradytictic (Howells et al. 1996, Parmalee and Bogan 1998). However, Obliquaria reflexa is a lureless, tachytictic summer brooder that releases conglutinates (Lefevre and Curtis 1912). The other primitive lampsilines are apparently lureless and either tachytictic (Glebula; Parker et al. 1984), possibly bradytictic (Cyrtonaias; Howells et al. 1996), or unreported (Plectomerus). More work on these species might help to shed light on the question of whether lures and 
long-term brooding in Lampsilini evolved in tandem. Also of interest are Ptychobranchus and Cyprogenia + Dromus, which evidently have reverted from lures to conglutinates (Zanatta and Murphy 2006). These taxa are bradytictic and release their elaborate conglutinates during a relatively short period in early spring when water temperatures rise (Jones and Neves 2002, Eckert 2003, Jones et al. 2004). Actinonaias ligamentina and $A$. pectorosa have also apparently lost the mantle lure and retained bradytictia (e.g., Surber 1912) (see previous section, Evolutionary transitions in host infection mechanisms). We are aware of one apparent reversion from bradytictia to tachytictia in Lampsilis: L. rafinesqueana is a tachytictic summer brooder in the upper Arkansas River system (Shiver 2002).

The mantle magazines and reactive release we have described in Quadrulini are a fascinating analogy to the protrusible marsupium and mantle lures of Lampsilini because the female can attract hosts and dispense glochidia. Therefore, it might seem that Quadrulini could also evolve long-term brooding. However, Quadrulini must release the glochidia from the demibranches into the mantle to make them available to hosts, so the female must still predict when the host is likely to arrive. Holding glochidia in the mantle magazine for long periods is apparently not an option because glochidia survive only a few days after release from the demibranches (Howard 1914, O'Brien and Williams 2002, Ingersoll et al. 2006).

\section{Evolution of Host Specificity}

Mussels exhibit varying degrees of host specificity. Some mussels apparently use only a single host species, whereas others use many (e.g., Trdan and Hoeh 1982, Gordon and Layzer 1993). The proportion of glochidia that successfully metamorphose can vary widely among host species. On good hosts, $>90 \%$ of attached glochidia might successfully metamorphose into juveniles, whereas only a small proportion might succeed on marginal host species. Differences also are observed among individual hosts of the same species (e.g., Riusech and Barnhart 2000, Eckert 2003). The different hosts that a mussel is able to use are not always closely related species. For example, some Epioblasma species metamorphose well on species of Cottus (Cottidae) and Etheostoma (Percidae) (Yeager and Saylor 1995). On the other hand, allopatric congeners or even allopatric populations of a host species can be less compatible than sympatric fish (Riusech and Barnhart 2000, Rogers et al. 2001, Eckert 2003). Together, these observations are fascinating because they show that mussels can adapt simultaneously to distantly related hosts, yet they can also be sensitive to what might be slight genetic differences among related species or populations of a single species. Unfortunately, most reports of mussel host use do not quantify metamorphosis success.

Host specificity, in an immunological sense, involves glochidia adapting to survive the innate defensive responses of the host fish. Innate immune responses are those that do not require previous exposure of the host individual to parasite antigens. Fish also can acquire immunity to glochidia via adaptive immune responses, including antibody production. However, antibody production and adaptive immunity develop slowly in fish and apparently affect glochidia mainly after multiple infections (Meyers et al. 1980, Bauer and Vogel 1987, Rogers and Dimock 2003, Dodd et al. 2005, 2006). Thus, the adaptive immune system of the host might render an individual host resistant to glochidia after previous infections, but it is the ability of the glochidia to circumvent the innate immune system of a fish species that determines whether that species is a good host.

One innate response of the host is encapsulation of attached parasites by epithelial cells called keratocytes (Arey 1921, Rogers-Lowery and Dimock 2006). This process is essential for successful parasitism by glochidia, but, paradoxically, encapsulation appears to be an anti-ectoparasite and wound-healing response. After encapsulation, cellular defenses such as granulocytes and phagocytes are concentrated at the capsule and can kill incompatible glochidia. Incompatible glochidia also are sloughed when the capsule degenerates or detaches as a small ball of tissue (Arey 1932a, b, Meyers et al. 1980, Waller and Mitchell 1989). Somehow, on suitable hosts, glochidia are able to be encapsulated without being killed or sloughed while they undergo their metamorphosis. The cellular and molecular mechanisms that allow larval mussels to evade the innate immune mechanisms, and which thereby determine host specificity, are not understood. Glochidia appear to be an excellent system for investigating the vertebrate innate immune system because the infections are easily manipulated and quantified, are generally nonpathogenic, and because a wide taxonomic variety of host-parasite pairings is available (Dodd et al. 2005, 2006).

Adaptation to a host species by natural selection requires that the glochidia make contact with that host. A larger proportion of glochidia that can contact a particular species of host will provide greater opportunity for selection of mussel genotypes that are compatible with that host. Therefore, mussels that have highly targeted lure or conglutinate strategies that restrict contact to particular host taxa should tend to be host specific, whereas mussels with less-targeted 
strategies should tend to be host generalists. However, species with nontargeted broadcast could evolve to be host specialists if one host species is overwhelmingly abundant, so that most glochidia encounter that host. This pattern could explain the apparently narrow host specificity of some mussels that lack highly specialized host attraction mechanisms but use abundant migratory hosts, such as M. margaritifera and Salmo sp. (e.g., Young and Williams 1984a), Fusconaia ebena and Alosa chrysochloris (Howard 1914), or Anodonta implicata and Alosa pseudoharengus (Davenport and Warmuth 1965, but see Kneeland and Rhymer 2008).

The selective pressures driving the evolution of mussel host specificity must be rather one-sided. Selective pressure on mussels to successfully parasitize fish is intense because their survival depends on it. On the other hand, there may be little selective pressure on fish to reject glochidia. Only heavy infections (hundreds of glochidia) are likely to be harmful to fish $>10$ $\mathrm{cm}$ in length (Kaiser 2005, Howerth and Keller 2006), and most natural infestations evidently involve only few dozen or less glochidia per fish (e.g., Neves and Widlak 1988 and references therein, Kneeland and Rhymer 2008). Glochidia do not reproduce on the host, and most do not grow, so energetic cost to the host via glochidia nutrition is probably slight. Harm to the host involves damage to the gills, which, in heavy infections, can cause elevated ventilation rates and greater susceptibility to low- $\mathrm{O}_{2}$ stress (Kaiser 2005). However, to our knowledge, no studies have examined whether hosting glochidia is more harmful than sloughing them. An examination of the gills of Micropterus salmoides after incompatible glochidia of Lasmigona costata were sloughed revealed morphological damage similar to that evident after successful metamorphosis of Lampsilis glochidia (MCB, unpublished observations). If rejection of glochidia incurs similar damage to hosting them, there would be no advantage to glochidia-specific innate immunity. It appears more likely that fish would evolve to be discriminating feeders and, thus, avoid contact with glochidia, perhaps driving the perfection of mimetic mantle lures and conglutinates in the process.

\section{Concluding Remarks}

The evolution of mussel parasitism on fish is an astonishing example of evolutionary adaptation and diversification. The radiation of most clades of Unionidae can be linked with development of particular suites of adaptations to use fish hosts. Analogous features have evolved repeatedly, so that our interpretations of function can be tested by comparative biology. This wonderful evolutionary tapestry is reason enough to conserve mussels. Sadly, the dependence of mussels on fish leaves mussels vulnerable, not only to their own frailties, but to those of their hosts as well. Conservation of mussels is completely dependent on conservation of their particular fish hosts and the habitat conditions in which they interact, a complication faced by few other taxa. There are numerous needs and opportunities for study of mussel-host interactions in diverse fields of study. In particular, careful observational studies of reproductive behavior, host use, and the fate of larval and juvenile stages in the field are needed. It is quite likely that such studies in the future will reveal facts of critical importance for conservation.

\section{Acknowledgements}

We extend our thanks to Dan Graf, Caryn Vaughn, and other reviewers for many helpful comments and suggestions. We thank Mike Baird, Jolene Bowers, Ben Dodd, Nathan Eckert, Scott Faiman, Todd Fobian, Paul Hartfield, Paul Johnson, Bri Kaiser, Steve McMurray, Andy Roberts, and Pamela Silver for contributions, comments, and corrections. We are grateful to Joe Ferraro and Mike Pinder for assistance with videotaping Epioblasma. Last, we thank the editors of the symposium for the opportunity to contribute this paper.

\section{Literature Cited}

Abelson, A., D. WeiHs, AND Y. Loya. 1994. Hydrodynamic impediments to settlement of marine propagules, and adhesive-filament solutions. Limnology and Oceanography 39:164-169.

AKIYAMA, Y., AND T. IwAKUma. 2007. Survival of glochidial larvae of the freshwater pearl mussel, Margaritifera laevis (Bivalvia:Unionoida), at different temperatures: a comparison between two populations with and without recruitment. Zoological Science 24:890-893.

Aldridge, D. C., AND A. L. McIvor. 2003. Gill evacuation and release of glochidia by Unio pictorum and Unio tumidus (Bivalvia:Unionidae) under thermal and hypoxic stress. Journal of Molluscan Studies 69:55-59.

Allen, D. C., B. E. Sietman, D. E. Kelner, M. C. Hove, J. E. Kurth, J. M. Davis, J. L. Weiss, and D. J. Hornbach. 2007. Early life-history and conservation status of Venustaconcha ellipsiformis (Bivalvia, Unionidae) in Minnesota. American Midland Naturalist 157:74-91.

Araujo, R., D. Bragado, AND M. A. Ramos. 2001. Identification of the river blenny, Salaria fluviatilis, as a host to the glochidia of Margaritifera auricularia. Iournal of Molluscan Studies 67:128-129.

Araujo, R., N. Càmara, and M. A. Ramos. 2002. Glochidium metamorphosis in the endangered freshwater mussel Margaritifera auricularia (Spengler, 1793): a histological 
and scanning electron microscopy study. Iournal of Morphology 254:259-265.

Araujo, R., AND M. A. Ramos. 1998. Description of the glochidium of Margaritifera auricularia (Spengler 1793) (Bivalvia, Unionoidea). Philosophical Transactions of the Roval Society of London: Series B-Biological Sciences 353:1553-1559.

Araujo, R., And M. A. Ramos. 2001. Life history data on the virtually unknown Margaritifera auricularia. Pages 143152 in G. Bauer and K. Wächtler (editors). Ecology and evolution of the freshwater mussels Unionoida. Ecological Studies 145. Springer-Verlag, Berlin, Germany.

AREY, L. B. 1921. An experimental study on glochidia and the factors underlying encapsulation. Iournal of Experimental Zoology 33:463-499.

AREY, L. B. 1932a. The formation and structure of the glochidial cyst. Biological Bulletin 62:212-221.

AREY, L. B. 1932b. A microscopical study of glochidial immunity. Journal of Morphology 53:367-379.

ASTM (AMERICAN SOCIETY OF TeSTING AND Materials). 2005. Standard guide for conducting laboratory toxicity tests with freshwater mussels (E2455-05). ASTM International Annual Book of Standards. Volume 11.05. American Society of Testing and Materials, West Conshohocken, Pennsylvania.

ATKINS, L. 1979. Observations on the glochidial stage of the freshwater mussel Hyridella (Hyridella) drapeta (Iredale) (Mollusca: Pelecypoda). Australian Journal of Marine Freshwater Research 30:411-416.

BAIRD, M. 2000. Life history and population structure of the spectaclecase mussel, Cumberlandia monodonta (Bivalvia, Margaritiferidae). MSc Thesis, Missouri State University, Springfield, Missouri.

BARNHART, M. C. 1997. Fertilization success in freshwater mussels. Report to the Missouri Department of Conservation, Columbia, Missouri. (Available from: http:// unionid.missouristate.edu/documents)

BARNhART, M. C. 2001. Fish hosts and culture of mussel species of special concern. Report to the Missouri Department of Conservation, Columbia, Missouri. (Available from: http://unionid.missouristate.edu/ documents)

BARNhART, M. C., AND A. D. Roberts. 1997. Reproduction and fish hosts of unionids from the Ozark Uplifts. Pages 1420 in K. S. Cummings, A. C. Buchanan, and L. M. Koch (editors). Conservation and management of freshwater mussels. II. Proceedings of a UMRCC Symposium, 16-18 October 1995, St Louis, Missouri. Upper Mississippi River Conservation Committee, Rock Island, Illinois.

BAUER, G. 1994. The adaptive value of offspring size among freshwater mussels (Bivalvia: Unionoidea). Iournal of Animal Ecology 63:933-944.

BAuer, G., AND C. Vogel. 1987. The parasitic stage of the freshwater pearl mussel (Margaritifera margaritifera L.). I. Host response to glochidiosis. Archiv für Hydrobiologie Supplement 76:393-402.

Beaumont, A. R., And D. A. Barnes. 1992. Aspects of veliger larval growth and byssus drifting of the spat of Pecten maximus and Aequipecten (Chlamys) opercularis. Interna- tional Council for Exploration of the Sea Journal of Marine Science 49:417-423.

Blalock-Herod, H. N., J. J. Herod, and J. D. Williams. 2002. Evaluation of conservation status, distribution, and reproductive characteristics of an endemic Gulf Coast freshwater mussel, Lampsilis australis (Bivalvia: Unionidae). Biodiversity and Conservation 11:1877-1887.

BlAẑEK, R., AND M. Gelnar. 2006. Temporal and spatial distribution of glochidial larval stages of European unionid mussels (Mollusca: Unionidae) on host fishes. Folia Parasitologica 53:98-106.

Bruenderman, S. A., AND R. J. Neves. 1993. Life history of the endangered fine-rayed pigtoe Fusconaia cuneolus (Bivalvia: Unionidae) in the Clinch River, Virginia. American Malacological Bulletin 10:83-91.

CALL, R. E. 1895. A study of the Unionidae of Arkansas, with incidental reference to their distribution in the Mississippi valley. Transactions of the Academy of Science of St Louis 7:1-64.

Campbell, D. C., J. M. Serb, J. E. Buhay, K. J. Roe, R. L. Minton, AND C. LydeARD. 2005. Phylogeny of North American amblemines (Bivalvia, Unionoida): prodigious polyphyly proves pervasive across genera. Invertebrate Biology 124:131-164.

Carman, S. M. 2007. Texas hornshell Popenaias popeii recovery plan. Conservation Services Division, New Mexico Department of Game and Fish, Santa Fe, New Mexico. (Available from: http://www.wildlife.state.nm.us/ conservation/documents/Invertebrates.htm)

Coker, R. E., A. F. Shira, H. W. Clark, AND A. D. Howard. 1921. Natural history and propagation of fresh-water mussels. Document No. 893. Bulletin of the US Bureau of Fisheries 37:77-181.

COKER, R. E., AND T. SURBER. 1911. A note on the metamorphosis of the mussel Lampsilis laevissimus. Biological Bulletin 20:179-182.

Cope, W. G., R. B. Bringolf, D. B. Buchwalter, T. J. Newton, C. G. Ingersoll, N. Wang, T. Augspurger, F. J. Dwyer, M. C. Barnhart, R. J. Neves, AND E. Hammer. 2008. Differential exposure, duration, and sensitivity of unionoidean bivalve life stages to environmental contaminants. Iournal of the North American Benthological Society 27:451-462.

Crownhart, A., B. Sietman, M. Hove, and N. Rudh. 2006. Quadrula metanevra glochidia metamorphose on select minnow species. Ellipsaria 8:6-7. (Available from: http:/ / ellipse.inhs.uiuc.edu/fmcs)

Cummings, K. S., And C. A. Mayer. 1993. Distribution and host species of the federally endangered freshwater mussel, Potamilus capax (Green, 1832) in the Lower Wabash River, Illinois and Indiana. Technical Report 1993(1):1-29. (Available from: Center for Biodiversity, Illinois Natural History Survey, 607 E. Peabody Dr., Champaign, Illinois 61820 USA.)

Dartnall, H. J. G., AND M. Walkey. 1979. The distribution of glochidia of the swan mussel, Anodonta cygnea (Mollusca) on the three-spined stickleback, Gasterosteus aculeatus (Pisces). Journal of Zoology London 189:31-37.

DAVENPORT, D., AND M. WARMUTH. 1965. Notes on the 
relationship between the freshwater mussel Anodonta implicata Say and the alewife Pomolobus pseudoharengus (Wilson). Limnology and Oceanography Supplement (Alfred C. Redfield 75 ${ }^{\text {th }}$ Anniversary Volume) 10:74-78.

DodD, B. J., M. C. BARnhart, C. L. Rogers-Lowery, T. B. Fobian, AND R. V. DiмOck. 2005. Cross-resistance of largemouth bass to glochidia of unionid mussels. Iournal of Parasitology 91:1064-1073.

DodD, B. J., M. C. Barnhart, C. L. Rogers-Lowery, T. B. Fobian, AND R. V. DiмOCK. 2006. Persistence of acquired immunity of largemouth bass to glochidia of unionid mussels. Iournal of Fish and Shellfish Immunity 21:473-484.

DudGEON, D., AND B. MORTON. 1984. Site determination and attachment duration of Anodonta woodiana (Bivalvia: Unionacea) glochidia on fish hosts. Iournal of Zoology London 204:355-362.

ECKERT, N. L. 2003. Reproductive biology and host requirements among isolated populations of Cyprogenia aberti (Conrad 1850). MSc Thesis, Missouri State University, Springfield, Missouri.

ENDLER, J. A. 1988. Frequency-dependent predation, crypsis and aposematic coloration. Philosophical Transactions of the Roval Society of London: Series B-Biological Sciences 319:505-523.

Fingerut, J. T., D. D. Hart, AND J. N. McNair. 2006. Silk filaments enhance the settlement of stream insect larvae. Oecologia (Berlin) 150:202-212.

FisheR, G. R., AND R. V. DiMOCK. 2002. Ultrastructure of the mushroom body: digestion during metamorphosis of Utterbackia imbecillis (Bivalvia: Unionidae). Invertebrate Biology 121:126-135.

FobIAN, T. 2007. Reproductive biology of the rabbitsfoot mussel (Quadrula cylindrica) (Say, 1817) in the upper Arkansas River system, White River system, and Red River system. MSc Thesis, Missouri State University, Springfield, Missouri.

FRYER, G. 1961. The developmental history of Mutela bourguignati (Ancey) Bourguignat (Mollusca: Bivalvia). Philosophical Transactions of the Roval Society of London: Series B-Biological Sciences 244:259-298.

Giusti, F., L. F. Castagnolo, L. M. Farina, and A. Renzoni. 1975. The reproductive cycle and the glochidium of Anodonta cygnea L. from Lago Trasimeno (central Italy). Monitore Zoologico Italiano 9:99-118.

Gordon, M. E., AND J. B. LAYZER. 1993. Glochidial host of Alasmidonta atropurpurea (Bivalvia: Unionoidea, Unionidae). Transactions of the American Microscopical Society 112:145-150.

GRAF, D. L. 1997. The effect of breeding period on the biogeography of freshwater mussels (Bivalvia: Unionoidea) in the Minnesota region of North America. Occasional Papers on Mollusks 5:393-407.

GrAF, D. L. 2000. The Etherioidea revisited: a phylogenetic analysis of hyriid relationships (Mollusca: Bivalvia: Paleoheterodonta: Unionoida). Occasional Papers of the University of Michigan Museum of Zoology 729:1-21.

Graf, D. L., And K. S. Cummings. 2006. Palaeoheterodont diversity (Mollusca: Trigonioida + Unionoida): what we know and what we wish we knew about freshwater mussel evolution. Zoological Journal of the Linnaean Society 148:343-394.

Graf, D. L., AND K. S. Cummings. 2007. Review of the systematics and global diversity of freshwater mussel species (Bivalvia: Unionoida). Iournal of Molluscan Studies 73:291-314.

GrAF, D. L., AND D. Ó FoIGHIL. The evolution of brooding characters among the freshwater pearly mussels (Mollusca: Bivalvia: Unionoidea) of North America. Journal of Molluscan Studies 66:157-170.

Haag, W. R., R. S. Butler, and P. W. Hartfield. 1995. An extraordinary reproductive strategy in freshwater bivalves: prey mimicry to facilitate larval dispersal. Freshwater Biology 43:471-476.

HaAG, W. R., AND J. L. Staton. 2003. Variation in fecundity and other reproductive traits in freshwater mussels. Freshwater Biology 48:2118-2130.

HaAG, W. R., AND M. L. Warren. 1997. Host fishes and reproductive biology of 6 freshwater mussel species from the Mobile Basin, USA. Iournal of the North American Benthological Society 16:576-585.

HAAG, W. R., AND M. L. WARREN. 1998. Role of ecological factors and reproductive strategies in structuring freshwater mussel communities. Canadian Journal of Fisheries and Aquatic Sciences 55:297-306.

HaAG, W. R., AND M. L. WARREN. 1999. Mantle displays of freshwater mussels elicit attacks from fish. Freshwater Biology 42:35-40.

HaAG, W. R., AND M. L. WARREN. 2000. Effects of light and presence of fishes on lure display and larval release behaviours in two species of freshwater mussels. Animal Behaviour 60:879-886.

HaAG, W. R., and M. L. Warren. 2003. Host fishes and infection strategies of freshwater mussels in large Mobile Basin streams, USA. Iournal of the North American Benthological Society 22:78-91.

HaAG, W. R., M. L. WARREN, AND M. Shillingsford. 1999. Host fishes and host-attracting behavior of Lampsilis altilis and Villosa vibex (Bivalvia: Unionidae). American Midland Naturalist 141:149-157.

Haggerty, T. M., J. T. Garner, And R. L. Rogers. 2005. Reproductive phenology in Megalonaias nervosa (Bivalvia: Unionidae) in Wheeler Reservoir, Tennessee River, Alabama, USA. Hydrobiologia 539:131-136.

Hartfield, P. D., AND R. S. Butler. 1997. Observations on release of superconglutinates by Lampsilis perovalis (Conrad 1834). Pages 11-13 in K. S. Cummings, A. C. Buchanan, C. A. Mayer, and T. Naimo (editors). Conservation and management of freshwater mussels. II. Initiatives for the future. Upper Mississippi River Conservation Committee, Rock Island, Illinois.

Hartfield, P., And E. Hartfield. 1996. Observations of the conglutinates of Ptychobranchus greeni (Conrad, 1834) (Mollusca: Bivalvia: Unionoidea). American Midland Naturalist 135:370-375.

HeARD, W. H. 1998. Brooding patterns in freshwater mussels. Malacological Review, Bivalvia 1, Supplement 7:105-121.

Heath, D., M. Hove, R. Benjamin, M. Endris, R. Kenyon, and J. KuRTH. 1998. Quadrula fragosa exhibit unusual reproduc- 
tive behaviors. Triannual Unionid Report 16:33. (Available from: http://ellipse.inhs.uiuc.edu/fmcs/tur/)

Hoen, W. R., A. E. Bogan, K. S. Cummings, and S. I. Guttman. 2002. Evolutionary relationships among the higher taxa of freshwater mussels (Bivalvia: Unionoida): inferences on phylogeny and character evolution from analyses of DNA sequence data. Malacological Review 31/32: 123-141.

Hoeh, W. R., A. E. Bogan, and W. H. Heard. 2001. A phylogenetic perspective on the evolution of morphological and reproductive characteristics in the Unionoida. Pages 257-280 in G. Bauer and K. Wächtler (editors). Ecology and evolution of the freshwater mussels Unionoida. Ecological Studies 145. Springer-Verlag, Berlin, Germany.

Hoggarth, M. A. 1999. Descriptions of some glochidia of the Unionidae (Mollusca: Bivalvia). Malacologia 41:1-118.

Hoggarth, M. A., And A. S. Gaunt. 1988. The mechanics of glochidial attachment (Mollusca: Bivalvia: Unionidae). Iournal of Morphology 198:71-81.

Hove, M. 1997. Ictalurids serve as suitable hosts for the purple wartyback. Triannual Unionid Report 11:4. (Available from: http://ellipse.inhs.uiuc.edu/fmcs/tur/)

HowARD, A. D. 1914. Experiments in propagation of freshwater mussels of the Quadrula group. Report of the US Commissioner of Fisheries 1913 Appendix 4:1-52. Issued separately as US Bureau of Fisheries Document No. 801. US Government Printing Office, Washington, DC.

HowARD, A. D. 1951. A river mussel parasitic on a salamander. Natural History Miscellanea 77:1-6.

Howard, A. D., AND B. J. Anson. 1922. Phases in the parasitism of the Unionidae. Iournal of Parasitology 9: 68-82.

HowARD, J. K., AND K. M. CufFEy. 2006. Factors controlling the age structure of Margaritifera falcata in 2 northern California streams. Iournal of the North American Benthological Societv 25:677-690.

Howells, R. G., R. W. NeCK, AND H. D. Murray. 1996. Freshwater mussels of Texas. University of Texas Press, Austin, Texas.

Howerth, E. W., AND A. E. Keller. 2006. Experimentally induced glochidiosis in smallmouth bass (Micropterus dolomieu). Veterinary Pathology 43:1004-1007.

Ingersoll, C. G., N. J. Kernaghan, T. S. Gross, C. D. Bishor, N. WANG, AND A. RoberTs. 2006. Laboratory toxicity testing with freshwater mussels. Pages 95-134 in J. L. Farris and J. H. van Hassel (editors). Freshwater bivalve ecotoxicology. Society of Environmental Toxicology and Chemistry, Pensacola, Florida.

JANSEN, W. A. 1991. Seasonal prevalence, intensity of infestation, and distribution of glochidia of Anodonta grandis simpsoniana Lea on yellow perch, Perca flavescens. Canadian Journal of Zoology 69:964-972.

JANSEN, W., G. BAuter, AND E. ZAHner-MeIKe. 2001. Glochidial mortality in freshwater mussels. Pages 185-212 in G. Bauer and K. Wächtler (editors). Ecology and evolution of the freshwater mussels Unionoida. Ecological Studies 145. Springer-Verlag, Berlin, Germany.

JiRKA, K. J., AND R. J. Neves. 1992. Reproductive biology of four species of freshwater mussels (Mollusca: Unionidae) in the New River, Virginia and West Virginia. Iournal of Freshwater Ecology 7:35-44.

JoKelA, J., AND P. PALOKANGAS. 1993. Reproductive tactics in Anodonta clams: parental host recognition. Animal Behaviour 46:618-620.

Jones, J. W., AND R. J. Neves. 2002. Life history and propagation of the endangered fanshell pearlymussel, Cyprogenia stegaria Rafinesque (Bivalvia: Unionidae). Iournal of the North American Benthological Society 21:76-88.

Jones, J. W., R. J. Neves, S. A. Ahlstedt, And E. M. Hallerman. 2006. A holistic approach to taxonomic evaluation of two closely related endangered freshwater mussel species, the oyster mussel Epioblasma capsaeformis and tan riffleshell Epioblasma florentina walkeri (Bivalvia: Unionidae). Journal of Molluscan Studies 72:267-283.

Jones, J. W., R. J. Neves, S. A. Ahlstedt, And R. A. Mair. 2004. Life history and propagation of the endangered dromedary pearlymussel (Dromus dromas) (Bivalvia:Unionidae). Iournal of the North American Benthological Society 23:515-525.

KaIser, B. E. 2005. The effects of glochidiosis on fish respiration. MSc Thesis, Missouri State University, Springfield, Missouri.

KAT, P. W. 1984. Parasitism and the Unionacea (Bivalvia). Biological Reviews 59:189-207.

Kennedy, T. B., And W. R. HaAg. 2005. Using morphometrics to identify glochidia from a diverse freshwater mussel community. Iournal of the North American Benthological Societv 24:880-889.

KneEland, S. C., AND J. M. Rhymer. 2008. Determination of fish host use by wild populations of rare freshwater mussels using a molecular identification key to identify glochidia. Journal of the North American Benthological Society 27:150-160.

Knudsen, K. A., And M. C. Hove. 1997. Spectaclecase (Cumberlandia monodonta) conglutinates unique, host(s) elusive. Triannual Unionid Report 11:2. (Available from: http: / / ellipse.inhs.uiuc.edu/fmcs/tur/)

Korniushin, A. V., And M. Glaubrecht. 2003. Novel reproductive modes in freshwater clams: brooding and larval morphology in Southeast Asian taxa of Corbicula (Mollusca, Bivalvia, Corbiculidae). Acta Zoologica (Stockholm) 84:293-315.

Kraemer, L. R. 1970. The mantle flap in three species of Lampsilis (Pelecypoda:Unionidae). Malacologia 10:225282.

Kurth, J. E., And M. C. Hove. 1997. Host fish suitability studies and host attracting behaviors of Tritogonia verrucosa, the pistolgrip. Triannual Unionid Report 12: 10. (Available from: http://ellipse.inhs.uiuc.edu/fmcs/ tur/)

Lane, D. J. W., A. R. Beaumont, and J. R. Hunter. 1985. Byssus drifting and the drifting threads of the young post-larval mussel Mytilus edulis. Marine Biology 84:301-308.

Lefevre, G., AND W. C. Curtis. 1910. Reproduction and parasitism in the Unionidae. Iournal of Experimental Zoologv 9:79-115. 
Lefevre, G., And W. T. Curtis. 1912. Studies on the reproduction and artificial propagation of fresh-water mussels. Bulletin of the US Bureau of Fisheries 30:105201.

LiLLIE, F. R. 1895. The embryology of the Unionidae. Iournal of Morphology 10:1-100.

López, M. A., C. R. Altaba, T. Rouault, and E. Gisbert. 2007. The European sturgeon Acipenser sturio is a suitable host for the glochidia of the freshwater pearl mussel Margaritifera auricularia. Iournal of Molluscan Studies 73:207-209.

Lydeard, C., M. Mulvey, And G. M. Davis. 1996. Molecular systematics and evolution of reproductive traits of North American freshwater unionacean mussels (Mollusca:Bivalvia) as inferred from $16 \mathrm{~S}$ rRNA gene sequences. Philosophical Transactions of the Roval Society of London: Series B-Biological Sciences 351:1593-1603.

Martel, A. L., AND J.-S. LAuZON-Guay. 2005. Distribution and density of glochidia of the freshwater mussel Anodonta kennerlyi on fish hosts in lakes of the temperate rain forest of Vancouver Island. Canadian Journal of Zoology 83:419-431.

MAtTeson, M. R. 1948. Life history of Elliptio complanatus (Dillwyn, 1817). American Midland Naturalist 40:690723.

Meyers, T. R., R. E. Millemann, and C. A. Fustish. 1980. Glochidiosis of salmonid fishes. IV. Humoral and tissue responses of Coho and Chinook salmon to experimental infection with Margaritifera margaritifera (L.) (Pelecypoda: Margaritanidae). Journal of Parasitology 66:274-281.

Morales, Y., L. J. Weber, A. E. Mynett, And T. J. Newton. 2006. Effects of substrate and hydrodynamic conditions on the formation of mussel beds in a large river. Iournal of the North American Benthological Society 25:664-676.

MoRRIS, T. J. 2006. Recovery strategy for the wavy-rayed lampmussel (Lampsilis fasciola) in Canada. Species at Risk Act Recovery Strategy Series. Fisheries and Oceans, Ottawa, Ontario. (Available from: http://www. sararegistry.gc.ca/plans/timelines_e.cfm)

Murphy, G. 1942. Relationship of the freshwater mussel to trout in the Truckee River. California Fish and Game 28: 89-102.

Nedeau, E. J., M. A. McCollough, AND B. I. Swartz. 2000. The freshwater mussels of Maine. Maine Department of Inland Fisheries and Wildlife, Augusta, Maine.

Neves, R. J., AND J. C. WidLAK. 1988. Occurrence of glochidia in stream drift and on fishes of the upper North Fork Holston River, Virginia. American Midland Naturalist 119:111-120.

NorkIS, S. M. 2001. Osteology of the southwestern darters, Etheostoma (Oligocephalus) (Teleostei, Percidae)—with comparison to other North American percid fishes. Occasional Papers of the University of Michigan Museum of Zoology 733:1-44.

O'BRIEN, C. A., AND J. BRIM Box. 1999. Reproductive biology and juvenile recruitment of the shiny-rayed pocketbook, Lampsilis subangulata (Bivalvia: Unionidae) in the Gulf Coastal Plain. American Midland Naturalist 142:129140.
O'Brien, C. A., AND J. D. Williams. 2002. Reproductive biology of four freshwater mussels (Bivalvia: Unionidae) endemic to the eastern Gulf Coastal Plain drainages of Alabama, Florida, and Georgia. American Malacological Bulletin 17:147-158.

O’Brien, C. A., J. D. Williams, and M. A. Hoggarth. 2003. Morphological variation in glochidia shells of six species of Elliptio from Gulf of Mexico and Atlantic Coast drainages in the southeastern United States. Proceedings of the Biological Society of Washington 116:719-731.

Ortmann, A. E. 1911. A monograph of the naiades of Pennsylvania. Parts I and II. Memoirs of the Carnegie Museum 4:279-347.

Ortmann, A. E. 1912. Notes upon the families and the genera of the Najades. Annals of the Carnegie Museum 8:222365.

Ortmann, A. E. 1921. South American Naiades; a contribution to the knowledge of the freshwater mussels of South America. Memoirs of the Carnegie Museum 8:451-670.

PARK, J. K., AND D. Ó FoIGHIL. Sphaeriid and corbiculid clams represent separate heterodont bivalve radiations into freshwater environments. Molecular Phylogenetics and Evolution 14:75-88.

PARKer, R. S., C. T. Hackney, And M. F. Vidrine. 1984. Ecology and reproductive strategy of a south Louisiana freshwater mussel, Glebula rotundata (Lamarck) (Unionidae: Lampsilini). Freshwater Invertebrate Biology 3:53-58.

Parmalee, P. W., and A. E. Bogan. 1998. The freshwater mussels of Tennessee. University of Tennessee Press, Knoxville, Tennessee.

Parodiz, J. J., And A. A. Bonetto. 1963. Taxonomy and zoogeographic relationships of the South American Naiades (Pelecypoda: Unionacea and Mutelacea). Malacologia 1:179-214.

PePI, V. E., AND M. C. Hove. 1997. Suitable fish hosts and mantle display behavior of Tritogonia verrucosa. Triannual Unionid Report 11:5. (Available from: http://ellipse. inhs.uiuc.edu/fmcs/tur/)

PIANKA, E. R. 1970. On $r$ and $K$ selection. American Naturalist 104:592-597.

Prezant, R. S., and K. Chalermwat. 1984. Flotation of the bivalve Corbicula fluminea as a means of dispersal. Science 225:1491-1493.

Riusech, F. A., AND M. C. BARNHARt. 2000. Host suitability and utilization in Venustaconcha ellipsiformis and Venustaconcha pleasii. Pages 83-91 in R. A. Tankersley, D. I. Warmolts, G. T. Watters, B. J. Armitage, P. D. Johnson, and R. S. Butler (editors). Freshwater Mollusk Symposia Proceedings. Ohio Biological Survey, Columbus, Ohio.

Roberts, A. D., AND M. C. BARnhart. 1999. Effects of temperature, $\mathrm{pH}$, and $\mathrm{CO}_{2}$ on transformation of glochidia of the flat floater mussel, Anodonta suborbiculata. Iournal of the North American Benthological Society 18:477-487.

RoE, K. J., AND P. D. HaRTfield. 2005. Hamiota, a new genus of freshwater mussel (Bivalvia: Unionidae) from the Gulf of Mexico drainages of the southeastern United States. Nautilus 119:1-10.

RoE, K. J., AND W. R. HoEH. 2003. Systematics of freshwater 
mussels (Bivalvia:Unionoida). Pages 91-122 in C. Lydeard and D. Lindberg (editors). Molecular systematics and phylogeography of mollusks. Smithsonian Press, Washington, DC.

RoE, K. J., AND C. LydeARD. 1998. Molecular systematics of the freshwater mussel genus Potamilus (Bivalvia: Unionidae). Malacologia 39:195-205.

Roe, K. J., A. M. Simons, and P. D. Hartfield. 1997. Identification of a fish host of the inflated heelsplitter Potamilus inflatus (Bivalvia: Unionidae) with a description of its glochidium. American Midland Naturalist 138: 48-54.

Rogers, C. L., AND R. V. DiMOck. 2003. Acquired resistance of bluegill sunfish Lepomis macrochirus to glochidia larvae of the freshwater mussel Utterbackia imbecillis (Bivalvia: Unionidae) following multiple infections. Iournal of Parasitology 89:51-56.

Rogers, S. O., B. T. WATSON, AND R. J. NeVEs. 2001. Life history and population biology of the endangered tan riffleshell (Epioblasma florentina walkeri) (Bivalvia:Unionidae). Iournal of the North American Benthological Society 20:582594.

Rogers-Lowery, C. L., AND R. V. DimOck. 2006. Encapsulation of attached ectoparasitic glochidia larvae of freshwater mussels by epithelial tissue on fins of naive and resistant host fish. Biological Bulletin 210:51-63.

SANDERSON, M. J., AND L. HufFORD (EDITORS). 1996. Homoplasy: the recurrence of similarity in evolution. Academic Press, San Diego, California.

SChwARTZ, M. L., AND R. V. DiMOCK. 2001. Ultrastructural evidence for nutritional exchange between brooding unionid mussels and their glochidia larvae. Invertebrate Biology 120:227-236.

SCHWEGMAN, J. E. 1998. Lure behavior in Toxolasma texasensis. Triannual Unionid Report 14:35. (Available from: http:/ / ellipse.inhs.uiuc.edu/fmcs/tur/)

SERB, J. M. 2006. Discovery of genetically distinct sympatric lineages in the freshwater mussel Cyprogenia aberti (Bivalvia: Unionidae). Journal of Molluscan Studies 72: 425-434.

Serb, J. M., and M. C. Barnhart. 2008. Congruence and conflict between molecular and reproductive characters when assessing biological diversity in the western fanshell Cyprogenia aberti (Bivalvia:Unionidae). Annals of the Missouri Botanical Garden (in press).

Serb, J. M., J. E. Buhay, and C. Lydeard. 2003. Molecular systematics of the North American freshwater bivalve genus Quadrula (Unionidae: Ambleminae) based on mitochondrial ND1 sequences. Molecular Phylogenetics and Evolution 28:1-11.

SHIVER, M. A. 2002. Reproductive biology of the Neosho mucket, Lampsilis rafinesqueana. MSc Thesis, Missouri State University, Springfield, Missouri.

Sigurdsson, J. B., C. W. Titman, and P. A. Davies. 1976. The dispersal of young post-larval bivalve molluscs by byssus threads. Nature 262:386-387.

SмiтH, D. G. 2000. On the taxonomic placement of Unio ochraceus Say, 1817 in the genus Ligumia (Bivalvia: Unionidae). Nautilus 114:155-160.
Smith, D. G., B. K. LANG, ANd M. E. Gordon. 2003. Gametogenetic cycle, reproductive anatomy, and larval morphology of Popenaias popeii (Unionoida) from the Black River, New Mexico. Southwestern Naturalist 48: 333-340.

Steingraber, M. T., M. R. Bartsch, J. E. Kalas, and T. J. NEwTON. 2007. Thermal criteria for early life stage development of the winged mapleleaf mussel (Quadrula fragosa). American Midland Naturalist 157:297-311.

SuRBER, T. 1912. Identification of the glochidia of freshwater mussels. Report and Special Papers of the US Bureau of Fisheries 1912:1-10. Issued separately as US Bureau of Fisheries Document 771.

Surber, T. 1913. Notes on the natural hosts of fresh-water mussels. Bulletin of the Bureau of Fisheries 32:103-116. Issued separately as US Bureau of Fisheries Document No. 778.

SURBER, T. 1915. Identification of the glochidia of fresh-water mussels. Report of the US Commissioner of Fisheries for 1914. Appendix 5:1-9. Issued separately as US Bureau of Fisheries Document No. 813.

Threlfall, W. 1986. Seasonal occurrence of Anodonta cataracta Say, 1817 glochidia on three-spined stickleback, Gasterosteus aculeatus Linnaeus. Veliger 29:231-234.

TRDAN, R. J., AND W. R. HoEH. 1982. Eurytopic host use by two congeneric species of freshwater mussel (Pelecypoda: Unionidae: Anodonta). American Midland Naturalist 108: 381-388.

UtTERBACK, W. I. 1915-1916. The naiades of Missouri. American Midland Naturalist 4:41-53,69-152,189204,244-273,311-327,339-354,387-400,432-464.

Vicentini, H. 2005. Unusual spurting behavior of the freshwater mussel Unio crassus. Iournal of Molluscan Studies 71:409-410.

Wächtler, K., M. C. Dreher-Mansur, and T. Richter. 2001. Larval types and early postlarval biology in Naiads (Unionoida). Pages 93-125 in G. Bauer and K. Wächtler (editors). Ecology and evolution of the freshwater mussels Unionoida. Ecological Studies 145. SpringerVerlag, Berlin, Germany.

Walker, K. F., M. Byrne, C. W. Hickey, And D. S. Roper. 2001. Freshwater mussels (Hyriidae) of Australasia. Pages 532 in G. Bauer and K. Wächtler (editors). Ecology and evolution of the freshwater mussels Unionoida. Ecological Studies 145. Springer-Verlag, Berlin, Germany.

Waller, D. L., AND L. G. Mitchell. 1989. Gill tissue reactions in walleye Stizostedion vitreum vitreum and common carp Cyprinus carpio to glochidia of the freshwater mussel Lampsilis radiata siliquoidea. Diseases of Aquatic Organisms 6:81-87.

WATERS, T. F. 1995. Sediment in streams: sources, biological effects, and control. American Fisheries Society Monograph 7. American Fisheries Society, Bethesda, Maryland.

WATtERS, G. T. 1999. Morphology of the conglutinate of the kidneyshell freshwater mussel, Ptychobranchus fasciolaris. Invertebrate Biology 118:289-295.

WAtTERS, G. T. 2001. The evolution of the Unionacea in North America, and its implications for the worldwide fauna. 
Pages 281-310 in G. Bauer and K. Wächtler (editors). Ecology and evolution of the freshwater mussels Unionoida. Ecological Studies 145. Springer-Verlag, Berlin, Germany.

WAtTERs, G. T. 2002. The kinetic conglutinate of the creeper freshwater mussel, Strophitus undulatus (Say 1817). Journal of Molluscan Studies 68:155-158.

WAtTERS, G. T. 2006. A brief look at freshwater mussel (Unionacea) biology. Pages 51-64 in J. L. Farris and J. H. Van Hassel (editors). Freshwater bivalve ecotoxicology. Society of Environmental Toxicology and Chemistry, CRC Press, Boca Raton, Florida.

WAtTers, G. T., AND S. H. O'DeE. 2000. Glochidial release as a function of water temperature: beyond bradyticty and tactyticty. Pages 135-140 in R. A. Tankersley, D. I. Warmolts, G. T. Watters, B. J. Armitage, P. D. Johnson, and R. S. Butler (editors). Freshwater Mussel Symposia Proceedings. Ohio Biological Survey, Columbus, Ohio.

WEISS, J. L., AND J. B. LAYZER. 1995. Infestations of glochidia on fishes in the Barren River, Kentucky. American Malacological Bulletin 11:153-159.

Welsh, J. H. 1933. Photic stimulation and rhythmical contractions of the mantle flaps of a lamellibranch. Proceedings of the National Academy of Science of the United States of America 9:755-757.

WiLSON, C. B. 1916. Copepod parasites of fresh-water fishes and their economic relations to mussel glochidia. Bulletin of the US Bureau of Fisheries 34:333-374. Issued separately as US Bureau of Fisheries Document No. 824.

Wilson, C. B., AND H. W. Clark. 1912. The mussel fauna of the Kankakee basin. Report and Special Papers of the US Fish Commission, 1911:1-52. Issued separately as US Bureau of Fisheries Document 758.

WooD, E. M. 1974. Some mechanisms involved in host recognition and attachment of the glochidium larva of Anodonta cygnea (Mollusca: Bivalvia). Lournal of Zoology 173:15-30.

Woody, C., AND L. Holland-Bartels. 1993. Reproductive characteristics of a population of the washboard mussel Megalonaias nervosa (Rafinesque 1820) in the upper Mississippi River. Journal of Freshwater Ecology 8:57-66.

YeAGER, B. L., AND R. J. Neves. 1986. Reproductive cycle and fish hosts of the rabbit's foot mussel, Quadrula cylindrica strigillata (Mollusca: Unionidae) in the upper Tennessee River drainage. American Midland Naturalist 116:329340.

YeAGER, B. L., AND C. F. SAYLOR. 1995. Fish hosts for four species of freshwater mussels (Pelecypoda: Unionidae) in the upper Tennessee River drainage. American Midland Naturalist 133:1-6.

YounG, M. R., And J. C. Williams. 1984a. The reproductive biology of the freshwater pearl mussel Margaritifera margaritifera (Linn.) in Scotland. I. Field studies. Archiv für Hydrobiologie 99:405-422.

Young, M. R., And J. C. Williams. 1984b. The reproductive biology of the freshwater pearl mussel Margaritifera margaritifera (Linn.) in Scotland. II. Laboratory studies. Archiv für Hydrobiologie 100:29-43.

Zale, A. V., AND R. J. Neves. 1982. Reproductive biology of four freshwater mussel species (Mollusca:Unionidae) in Virginia. Freshwater Invertebrate Zoology 1:17-28.

Zanatta, D. T., S. J. Fraley, AND R. W. Murphy. 2007. Population structure and mantle display polymorphisms in the wavy-rayed lampmussel, Lampsilis fasciola (Bivalvia: Unionidae). Canadian Journal of Zoology 85:11691181.

ZanATTA, D. T., AND R. W. MuRPHy. 2006. Evolution of active host-attraction strategies in the freshwater mussel tribe Lampsilini (Bivalvia: Unionidae). Molecular Phylogenetics and Evolution 41:195-208.

Zimmerman, L. L., AND R. J. Neves. 2001. Effects of temperature on longevity and viability of glochidia of freshwater mussels (Bivalvia: Unionidae). American Malacological Bulletin 17:31-35.

Received: 6 August 2007 Accepted: 19 February 2008

APPENDIx. Dimensions of glochidia of 128 species of Unionidae and Margaritiferidae. Size is the average of length (L) and height (H). Shape is the H:L ratio. Measurements of species reported by multiple sources were averaged. Units are $\mu \mathrm{m}$.

\begin{tabular}{|c|c|c|c|c|c|}
\hline Species & Length & Height & Size & Shape & Source $^{a}$ \\
\hline Actinonaias pectorosa & 244.0 & 253.0 & 248.5 & 1.04 & $\mathrm{D}$ \\
\hline Alasmidonta marginata & 344.5 & 372.5 & 358.5 & 1.08 & $\mathrm{~K}, \mathrm{D}$ \\
\hline Alasmidonta undulata & 353.0 & 371.0 & 362.0 & 1.05 & $\mathrm{D}$ \\
\hline Alasmidonta viridis & 303.5 & 253.0 & 278.3 & 0.83 & $\mathrm{~K}, \mathrm{D}$ \\
\hline Anodonta beringiana & 289.0 & 290.0 & 289.5 & 1.00 & $\mathrm{D}$ \\
\hline Anodonta cygnea & 351.0 & 351.0 & 351.0 & 1.00 & $\mathrm{D}$ \\
\hline Anodonta implicata & 343.0 & 348.0 & 345.5 & 1.01 & $\mathrm{D}$ \\
\hline Anodonta kennerlyi & 352.0 & 344.0 & 348.0 & 0.98 & $\mathrm{D}$ \\
\hline Anodonta suborbiculata & 325.0 & 323.0 & 324.0 & 0.99 & $\mathrm{D}$ \\
\hline Anodontoides ferussacianus & 326.5 & 327.0 & 326.8 & 1.00 & $\mathrm{~K}, \mathrm{D}$ \\
\hline
\end{tabular}


Appendix. Continued.

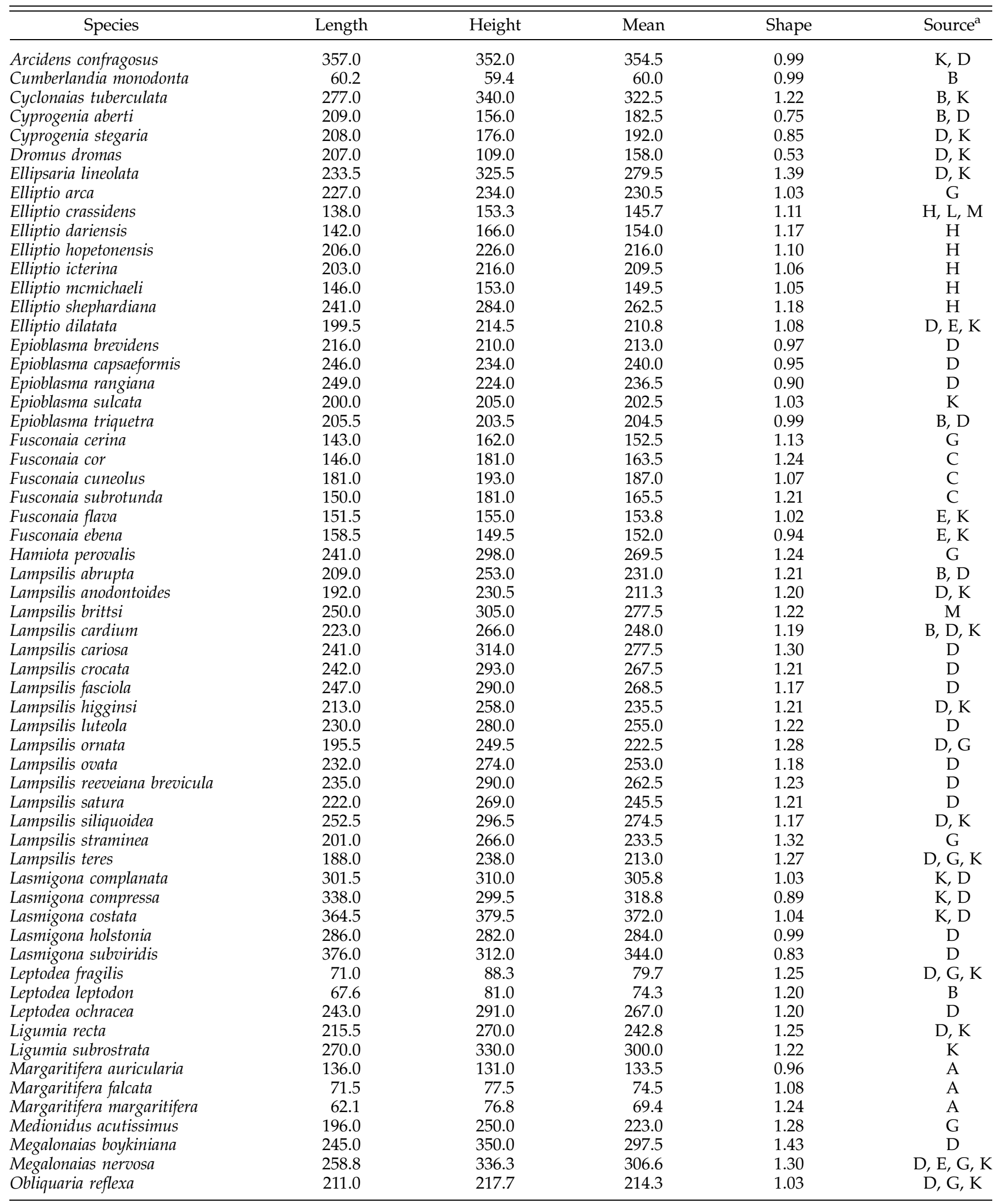


Appendix. Continued.

\begin{tabular}{|c|c|c|c|c|c|}
\hline Species & Length & Height & Mean & Shape & Source $^{a}$ \\
\hline Obovaria olivaria & 206.0 & 261.5 & 233.8 & 1.27 & $\mathrm{D}, \mathrm{K}$ \\
\hline Obovaria subrotunda & 177.0 & 204.0 & 190.5 & 1.15 & $\mathrm{D}$ \\
\hline Obovaria unicolor & 171.5 & 220.5 & 196.0 & 1.29 & $\mathrm{D}, \mathrm{G}$ \\
\hline Pegias fabula & 386.0 & 322.0 & 354.0 & 0.83 & $\mathrm{D}$ \\
\hline Pleurobema decisum & 203.0 & 198.0 & 200.5 & 0.98 & G \\
\hline Pleurobema decisum & 141.0 & 136.0 & 138.5 & 0.96 & G \\
\hline Pleurobema oviforme & 193.0 & 185.0 & 189.0 & 0.96 & $\mathrm{C}$ \\
\hline Pleurobema solida & 160.0 & 160.0 & 160.0 & 1.00 & K \\
\hline Popenaias popeii & 219.0 & 208.0 & 213.5 & 0.95 & $\mathrm{~J}$ \\
\hline Potamilus alatus & 218.0 & 379.0 & 298.5 & 1.74 & $\mathrm{D}, \mathrm{K}$ \\
\hline Potamilus amphichaena & 112.0 & 171.0 & 141.5 & 1.53 & D \\
\hline Ptychobranchus fasciolaris & 173.0 & 187.0 & 180.0 & 1.08 & $\mathrm{D}$ \\
\hline Ptychobranchus greeni & 187.0 & 227.0 & 207.0 & 1.21 & $\mathrm{D}$ \\
\hline Ptychobranchus occidentalis & 200.0 & 238.0 & 219.0 & 1.19 & $\mathrm{D}$ \\
\hline Ptychobranchus subtentum & 185.0 & 233.0 & 209.0 & 1.26 & $\mathrm{~B}, \mathrm{D}$ \\
\hline Pyganodon cataracta & 376.0 & 363.0 & 369.5 & 0.97 & $\mathrm{D}$ \\
\hline Pyganodon corpulenta & 350.0 & 350.0 & 350.0 & 1.00 & $\mathrm{~K}$ \\
\hline Pyganodon doliaris & 361.0 & 342.5 & 351.8 & 0.95 & $\mathrm{D}$ \\
\hline Pyganodon grandis & 375.0 & 381.3 & 378.2 & 1.02 & $\mathrm{~K}, \mathrm{D}, \mathrm{G}$ \\
\hline Quadrula asperata & 232.0 & 289.0 & 260.5 & 1.25 & G \\
\hline Quadrula cylindrica & 200.0 & 200.0 & 200.0 & 1.00 & $\mathrm{~B}$ \\
\hline Quadrula metanevra & 174.0 & 196.0 & 185.0 & 1.13 & $\mathrm{E}, \mathrm{K}$ \\
\hline Quadrula nodulata & 200.0 & 250.0 & 225.0 & 1.25 & $\mathrm{~K}$ \\
\hline Strophitus subvexus & 343.0 & 322.5 & 332.8 & 0.94 & $\mathrm{D}, \mathrm{G}$ \\
\hline Strophitus undulatus & 356.5 & 290.0 & 323.3 & 0.81 & $\mathrm{D}, \mathrm{K}$ \\
\hline Strophitus u. tennesseensis & 363.0 & 295.0 & 329.0 & 0.81 & D \\
\hline Toxolasma lividus & 182.0 & 205.0 & 193.5 & 1.13 & B \\
\hline Toxolasma parvus & 163.0 & 186.0 & 174.5 & 1.14 & $\mathrm{~B}$ \\
\hline Truncilla donaciformis & 60.0 & 63.0 & 61.5 & 1.05 & K \\
\hline Truncilla truncata & 60.0 & 70.0 & 65.0 & 1.17 & $\mathrm{~K}$ \\
\hline Utterbackia imbecillis & 307.0 & 295.0 & 301.0 & 0.96 & $\mathrm{D}, \mathrm{K}$ \\
\hline Venustaconcha ellipsiformis & 226.0 & 285.0 & 255.5 & 1.26 & D \\
\hline Villosa iris & 232.5 & 298.0 & 265.3 & 1.28 & $\mathrm{D}, \mathrm{K}$ \\
\hline Villosa lienosa & 208.0 & 272.5 & 240.3 & 1.31 & $\mathrm{G}, \mathrm{M}$ \\
\hline Villosa perpurpurea & 165.0 & 241.0 & 203.0 & 1.46 & D \\
\hline Villosa trabalis & 190.7 & 258.0 & 224.3 & 1.35 & $\mathrm{D}, \mathrm{K}$ \\
\hline Villosa vibex & 239.5 & 306.0 & 272.8 & 1.28 & $\mathrm{D}, \mathrm{G}$ \\
\hline Villosa villosa & 245.0 & 303.0 & 274.0 & 1.24 & D \\
\hline
\end{tabular}

${ }^{\text {a }} \mathrm{A}=$ Araujo and Ramos 1998, B = MCB, unpublished data, C = Bruenderman and Neves 1993, D = Hoggarth 1999, E = Howard $1914, \mathrm{~F}=$ Howells et al. 1996, G = Kennedy and Haag 2005, H= O'Brien et al. 2003, I = Roe et al. 1997, J= Smith et al. 2003, K = Surber 1912, L = Surber 1915, M = Utterback 1915-1916 